\title{
PROFIT SHARING IN GERMAN FIRMS
}

\section{Institutional Framework, Participation, Microeconomic Effects, and Comparisons with the United States}

Vivian Carstensen, Knut Gerlach, Olaf Hübler

\section{INTRODUCTION}

While the idea of profit sharing has existed for more than a hundred years in the United States (Gilman 1891) and in Germany (v. Thünen 1850) and generally advantages outweigh the disadvantages from a theoretical viewpoint, this form of payment is not widespread. Nevertheless, the debate surrounding this topic is rekindled from time to time.

Recently research on profit sharing (PS) has been stimulated in Europe by the PEPPER-Report (Uvalic 1991), which contains a detailed description and analysis of profit and revenue sharing in the member states of the EU and in the United States by the publication of "Paying for Productivity" (Blinder 1990), a collection of papers presenting a survey of the literature on the effects of pay schemes, including PS and worker participation in decision making, on labor productivity. In both Germany and the United States, the productivity effects of PS and, especially in the U.S., the slowdown of productivity constitute significant themes of the ongoing research (Kruse 1993). Due to various publications of Weitzman $(1983,1984,1985,1987)$ the impact of PS on employment and inflation has been at the core of the debare in the Unired States, while in the European tradition the consideration of microeconomic productivity effects is coupled with investigations of the impact of PS on investment, absenteeism, separation, and the identification of workers with the firm. Additionally, in Germany PS is recommended as an instrument for the New Lander to reduce labor costs, to extend employment, and to increase or maintain the competitiveness of German firms in the more integrated Europe.

Furthermore, it is asked why so few firms introduce PS, whether PS is merely another form of payment compared with wages, whether these two and other instruments are used complementarily or substitutively. The limited diffusion of PS 
leads to the question of whether tax incentives can help to adopt PS, whether additional conditions like nonpecuniary participation of workers are necessary for the success of PS, and whether the decision to opt for PS depends on the structure of markets. Disagreement exists in all these fields-from both the theoretical position and the empirical evidence.

The chapter is organized as follows. The next (second) section gives an overview of the institutional and legal framework of PS in Germany, describes typical PS schemes, and contains the principal legal issues of PS and some remarks on the growth and distribution of PS in the United States. Contradictory hypotheses concerning PS are formulated in pages 173-177. Subsequent pages describe our German firm data set. Pages 177-196 present the empirical analysis, i.e. descriptive statistics and first results of the econometric analysis concerning participation of firms in PS schemes and microeconomic effects of PS, where pure PS productivity effects and joint effects with workers' nonpecuniary participation are investigated. Comparisons with results of U.S. studies are included. Pages 196-201 conclude the chapter.

\section{INSTITUTIONAL FRAMEWORK AND TYPICAL PS SCHEMES}

\section{Legal Basis in Germany}

Savings schemes offering incentives in the form of tax concessions and cash premiums to workers and firms were first enacted in 1961. The goal of these schemes was to foster asset accumulation of employees with moderate annual incomes in order to redress the unequal distribution of wealth which resulted from the economic reconstruction after the second world war. With the enactment of the Property Development Acr (Asset Participation Act, effective January 1, 1984) and its subsequent amendments - the most recent of January 1, 1994-the participation of employees in the assets of firms was specifically stimulated. Before 1984, property development via building societies (savings and loan associations) enjoyed the highest priority. After 1984 this ordering of priorities was reversed.

The catalog of forms of participation fostered by tax concessions and cash premiums primarily comprises: loans and debentures by employees, rights of usufrucr, silent partnerships, cooperative associations, and equities. The financial participation of employees in firms employing them are subsidized with a cash premium of 20 percent of a maximum annual amount of DM936 per employee. This subsidy, however, is paid only to single (married) employees with annual gross incomes not exceeding DM27,000 (DM54,000). According to section 19a of the Income Tax Law, shares or other forms of financial participation of employees are exempt from tax and social security payments. These exemptions are valid for firms and employees under certain conditions, i.e. they must not exceed DM500 per employee and year, the firm can subsidize the acquisition of the share or the financial participation up to 50 percent of its value, and for a period of six 
years the employee cannot dispose of his/her financial participation. It is of special significance that the property promotion possibilities of the Income Tax and the Property Development Act can be combined. Apparently, this can explain the finding that in company sharing schemes a combination of gain or profit sharing and participarion in the firm's assets is chosen by firms and workers. The gains accruing to both parties, the employee and employer, by this combination are illustrated by an example (valid for 1989, the year of our firm data sample):

An unmarried employee with an annual income less than DM27,000 opts for a capital participation of DM936 in the enterprise for a period of six years. A cash premium of 20 percent paid out of tax revenues reduces his expenditures to DM749. The employee's capital participation is supplemented by an amount of DM500 exempt from tax and social security payments. The firm makes this contribution on the basis of a gain or profit sharing scheme, where gain sharing refers to a participation of employees in the firm's revenue in case of reduced delivery times, for example. Consequently, the employee acquires a capital participation of DM1,436 with expenditures of DM749. The firm's contribution (DM500), evidently, leads to a reduction in profits and taxes. With a marginal tax rate of 60 to 75 percent, the firm is capable of attracting additional financial resources of DM1,436 by giving up profits of DM125 to 200. A longterm analysis, however, has to take into account that after a period of six years the worker's capital participation as well as his invested gain or profit shares can be terminated. Schneider and Zander (1990: 117) point out that in recent years cash benefits as gain or profit shares have petered out in favor of investments financed from this source. Evidently, this result favorable both for the employee and the firm is attained by reduced taxes and by a subsidy.

This example helps to explain why in recent years elements of gain or profit sharing and of capital participation often are interrelated. Gain or profit sharing can be based on economic performance of the firm (e.g., production performance), returns (e.g., revenue) or profits according to the balance sheet. In most participation schemes profit sharing is preferred to sharing on the basis of revenue or production performance (Schneider and Zander 1990: 79). Problems to be solved in profit sharing schemes concern the definition of profits (interest on equity capital, earnings of owner-managers, risk premiums), the distribution of profits between capital and labor, and the individual distribution of profit shares between employees. Numerous procedures and guidelines have been developed by firms to resolve these issues (Schanz and Riekhof 1983: 44).

Evidently, profit shares do not have to be invested in the firm since they can be part of the normal remuneration as quasi-rents which are shared between capital and labor. In that case, however, the monetary and fiscal advantages of the official property promotion are no longer available, and the consequences of genuine profit 
sharing and profit sharing disguised as quasi-rents might differ with respect to taxation.

Legally, profit sharing in firms can be based on individual contracts (firm and worker) or on contracts between the works council and the firm. Due to legal aspects and psychological points of view (motivational considerations) the literature usually is in favor of contracts between the works council and the firm. The capital participation of employees can be independent of the legal constitution of the firm (rights of usufruct, loans of employees), or it may be tied to the legal constitution of the firm, if, for example, employee stocks are offered. Additionally, capital participation of workers can take the form of equity capital or long-term liabilities. The choice berween equity capital and long-term liabilities is determined by the following considerations: the firm's capital structure (i.e., its mix between equity capital and liabilities), employees' participation in profits and losses, and the stronger motivational effects due to the status of co-ownership. Furthermore, employees can participate directly or via an intermediary association in the firm's capital.

Investigations of gain sharing and capital participation (Uvalic 1991; Guski and Schneider 1983, 1986; Schanz and Riekhoff 1983) demonstrate that these participations are distributed unequally according to sectors of economic activity, firm size classes, age of firms, legal constitution of firms, and regions. The determinants of the unequal distribution, however, have not been analyzed theoretically and empirically. The number of firms with gain sharing and/or capital participation schemes has increased substantially since the enactment of the Property Development Act in 1984, and, apparently, employees tend to make larger contributions to the capital of firms via gain or profit sharing than in the antecedent period (Guski and Schneider 1986). A recent study by the Ministry of Labor in Baden-Württemberg (Ministerium für Arbeit, Gesundheir, Familie und Sozialordnung des Landes Baden-Württemberg 1990), however, draws attention to the fact that in general employees are poorly informed about cash benefits and tax subsidies offered in connection with gain sharing and capital participation.

\section{PS schemes}

From April 1991 to June 1992 we collected data from 33 PS firms in Lower Saxony and Baden-Württemberg (interview and questionnaire). In the interviews we encountered a variety of PS schemes, which are the basis of the empirical investigation (for a description of the data set and the empirical results see pages 177-196). In the sequel six typical PS schemes are presented: sharing of revenue or value-added, employee stock (on privileged terms), PS with a silent partnership, asset participation on the basis of loans, firm performance bonus, and sharing of profits per sales. Each scheme is described within the context of the firms which introduced it (see Table 7.1). In many firms mixed schemes exist and two or more of the pure schemes coexist in some firms, respectively. 


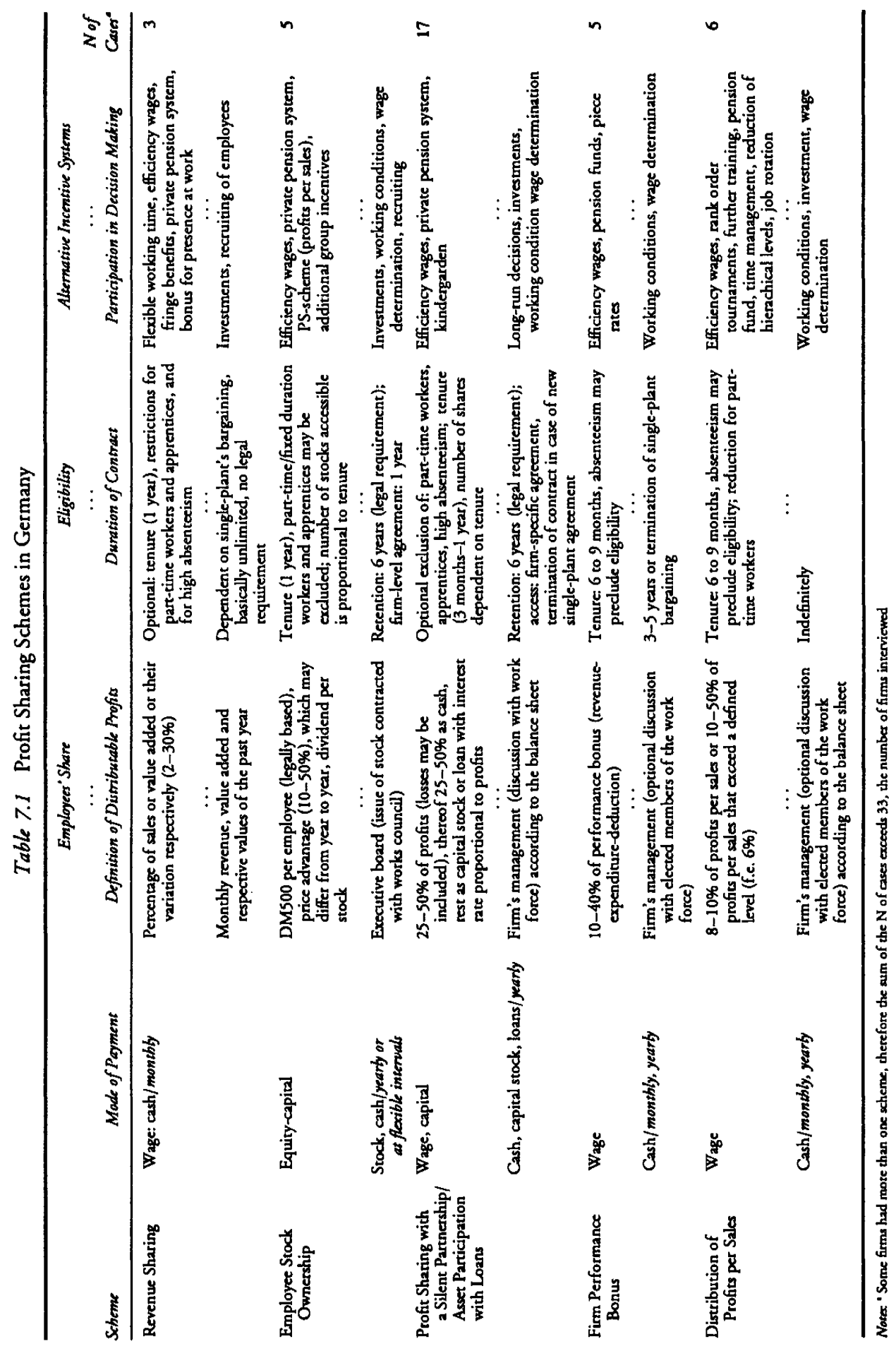




\section{Revenue or Value-added Sharing}

This is a simple and straightforward form of a sharing scheme. Employees might receive 2-10 percent of monthly revenue or value-added (excluding sales tax) with a time lag of one month or they get 10-30 percent of the deviation between the actual and past years value of revenue or value added, respectively. The individual distribution of this sum is uncomplicated. It is divided by the number of employees or distributed according to the individual annual income without bonus payments. On average, employees' revenue sharing amounts to $10-15$ percent of total annual payroll (excluding fixed labor costs). It is frequently combined with alternative incentives like flexible working time, a variety of fringe benefits and with workers' participation in decision making in the production process.

\section{Employee Stock Ownership on Privileged Terms}

The 1984 Income Tax Law (section 19a), in conjunction with the Property Development Act, usually provides the legal basis for the issue of employee stock. This issue does not have to follow a fixed schedule, however; it depends on actual annual profits and is negotiated between the executive board and the corporation's works council. The following details typically characterize the employee stock ownership schemes: Tenure of a minimum of one year is required for participation, and a positive correlation is stipulated between individual tenure and the amount of stock offered for purchase. The price of preference stock normally does not exceed two thirds of the market rate at the time of the contract, and the price advantage offered by the firm is exempted from income tax and social security contributions up to DM500 (Income Tax Law, section 19a). In addition, the acquisition of employee stock is subsidized with a premium of 20 percent up to DM936 (Property Development Act). To obtain this premium employees must retain the shares for six years. The corporations sometimes request a commitment of less than three years for offering the price advantage.

\section{PS with a Silent Partnership}

Frequently, this kind of sharing is established in medium-sized or small firms, especially in corporations with limited liability. At first sight it seems to be the typical German type of profit sharing, but uniform and firmly established procedures cannot be observed. The conditions of participation differ between firms, and are usually established by single-plant bargaining. The observed sharing arrangements differ in requirements for joining the program (in/excluding parttime workers, apprentices, or retired workers). A gain sharing part and a cash component may be included. This variation is not surprising as profit sharing is absolutely voluntary, often introduced by entrepreneurs who feel morally responsible and tend to collaborate with their employees as partners. 
Usually, all employees-with the possible exception of part-rime workers and apprentices - have the option to become silent partners. Sometimes, workers with high rates of absenteeism are precluded. Up to a maximum of 25 percent of toral profits according to the financial statement is distributed to employees as silent partners. Silent partners participate in the losses of the firm. This participation is, however, limited to the amount of their equity capital. The firm's management determines and defines the amount of the annual distributable profits according to the financial statement (Handelsbilanz), which allows a more extensive inclusion of expenditures than the legally required balance sheet (Steuerbilanz). A group of elected representatives of employees, however, is informed by the firm about the financial statement and is called upon to discuss issues concerning the determination of distributable profits and the firm's policy. The intention is to obtain consensus regarding the magnitude of distributable profits. Profits are distributed individually per capita, according to individual wages and to the capital stock held by each employee. The mix of these possibilities within a firm's scheme varies between firms. New silent partners are granted a rather small amount as a first share.

This PS scheme can be supplemented by additional components. All employees might receive payments on the basis of the atrainment of specific goals as, for example, increased productivity or output. These bonus payments (gain sharing) amount to approximately 25 percent of the profits accruing to employees as the already mentioned capital stock. The rate of interest paid to the silent partners exceeds the current discount rate by at least two percentage points, and may be restricted to a maximum. The interest rate can also be dependent on the ratio of profits to sales, with higher ratios providing higher interest rates.

Normally, the silent partnership contract remains valid until the employee retires. When the capital stock of an employee exceeds a certain amount, DM10,000 for example, he/she can require a payment in cash. A cash payment may be stipulated, too, if more than 25 percent of the assets of the firm are sold, if the worker dies, quits, or is dismissed. In case of a quit or dismissal the cash payment of a silent partner might be reduced by 1 percent for each year between the expected year of retirement and the year of separation. However, a silent partner is not allowed to sell his/her capital stock to other persons.

\section{Asset Participation on the Basis of Loans}

The institutional framework of this kind of asset participation is almost identical to that for PS with a silent partnership. The legal status of capital differs since an employee's share is not equity capital. The firm is in the position of a debtor. The two systems differ slightly in the number of additional sharing systems, which are established in the firm, too (see also Figure 7.1), and in the formal access for employees to information concerning the firm's business transactions and accounts (due to German commercial code). The de facto access (especially the right to control the balance sheet), however, does not vary between these forms: usually it is restricted by firm level agreements. 


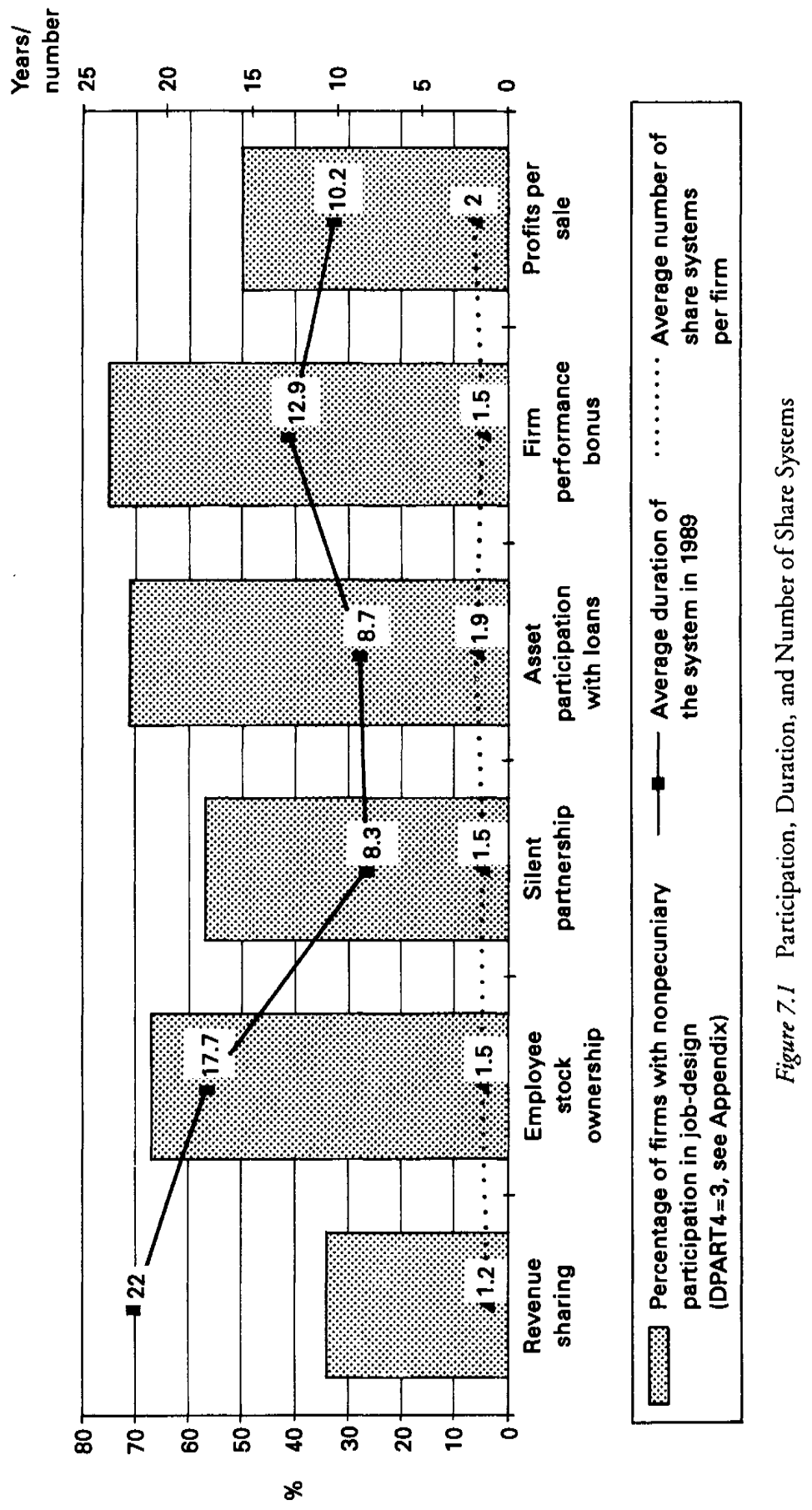




\section{Firm Performance Bonus}

Often PS or bonus payments are interpreted as a group incentive or group bonus which are used as substitutes for or complements to individual incentives as, e.g., piece rates. Their goals are to motivate employees to work more efficiently, to reduce labor turnover and absenteeism. Normally, employees with tenure of at least six months participate in profits, but they do not share in losses.

To determine the profits to be shared (firm performance bonus) first the difference is calculated between revenue and expenditures (variable/fixed labor costs, capital costs, depreciation, investments, energy costs, marketing costs, etc.). Usually, this is computed on a monthly basis. Second, a certain portion of this difference (increasing with its size) is deducted as a reserve for contingencies. The goal is to secure sufficient means for avoiding firm's losses through price or demand shocks, and to elicit high efforts from employees in each month. Otherwise employees could work very hard one month to obtain the full bonus, and shirk the next month, since they do not participate in losses. Therefore, this reserve can be interpreted as a bond, deferred until December of the current year.

The residual profit (revenue minus expenditures minus deduction) is the monthly bonus to be shared. Employees will obtain $10-40$ percent, while 20 percent are set aside for reactions to changes in market conditions (e.g., necessary investments). If severe contingencies have not occurred, and the work force's mean effort was high, the deferred bond is shared in December. Frequently, the individual distribution of the performance bonus is based on individual income. If an employee's absenteeism exceeds a certain level — for whatever reason - she/he is excluded from bonus payments during the relevant period. All calculations are performed by the firm's management. It gets advice, however, in regular discussions with several elected members of the work force or members of the works council.

\section{Distribution of Profits per Sales}

The work force receives up to 10 percent of profits per sales or obtains between 10 and 50 percent of the excess, if the profits per sales exceed an a priori defined level. The individual distribution is in accordance with monthly or yearly income. It may be supplemented by a distribution per capita. Apparently, the duration of the direct profits-per-sales schemes is unlimited. This may be interpreted as an intention to strengthen confidence between workers and management.

Evidently, on a microeconomic level a variety of compensation schemes exists which includes elements of profit and revenue sharing. Many of them can be interpreted as components of personnel management trying to improve employees' motivation and productivity. The motivational effect of sharing schemes is often considered in combination with (voluntary) employee involvement in decisionmaking. 


\section{Schemes, Legal Issues, Growth, and Prevalence of PS in the United States}

Three types of PS plans can be distinguished. In cash or current distribution plans a profit-related bonus is paid directly to employees at regular intervals. These profit shares are tax-deductible for the employee. The employer, however, has to pay regular income taxes for the bonus (Kruse 1991). In deferred plans, a bonus is paid to employee accounts of a pension or profit sharing trust. The employees receive the accumulated values of the accounts at retirement or separation from the firm. The accounts are subject to vesting requirements. The payments are taxable upon withdrawal at the time of retirement. In combination plans a current or deferred payment of the profit-related bonus is feasible.

Since 96 percent of profit sharing plans in the United States are deferred profit sharing trusts (Blasi 1988) and since they are similar to ESOPs, a brief discussion of the major forms of defined-contribution plans (profit sharing plans, ESOPs, $401(\mathrm{k})$ plans) is warranted. Contributions to deferred profit sharing plans are exempt from taxation (Blasi and Kruse 1991). These plans must be permanent and established for the exclusive benefit of employees. The law states eligibility requirements for participation in plans and requires that the plan has a definite formula for the allocation of benefits to individual employees and a definite schedule for the vesting of the accounts of employees. Discretionary formulas for calculating the contribution of the employer to the plan are permissible. The profits shared with employees can to a certain degree be invested in the company's stock.

An ESOP may borrow money in order to purchase employer stock (Conte and Svejnar 1990; Blasi and Kruse 1991). The loan is paid back as annual contributions are made to the Employee Stock Ownership Trust. The firms get a tax deduction for the repayment of the principal and the payments of the interest of the loan. As the loan is repaid, the shares of the stock are allocated to the individual investment accounts of employees. Employees can sell the shares at retirement or when separating from the company. Since the allocation of stock to individual employees can be based on profits it is difficult to distinguish between an ESOP and a deferred profit sharing plan. Blasi (1990: 174) argues: "More systematic data will probably conclude that the distinction between 'profit sharing' and 'employer ownership' is largely bogus, the result of a massive disguising bias."

In $401(\mathrm{k})$ and other thrift plans employees purchase company stocks by savings, which are deducted from their salaries (Blasi and Kruse 1991). As an incentive for encouraging employees to participate, employers typically make a contribution to these plans; such contributions are tax-deductible up to 15 percent of the income of the participating employees. Since the matching contributions of employees may be based on profits, these plans can be considered as deferred profit sharing plans.

According to Kruse (1991) the number of participants in deferred profit sharing plans was 9.9 (15.4) million in 1980 (1986) representing 13.3 (18.4) percent of the private work force. ESOPs covered 6.2 (11.1) percent of the private work force 
in 1980 (1986). Separate data for 401 (k) plans are not available. Interestingly, only 3.0 percent of the approximately half-million profit sharing plans were a combination of a deferred trust and cash profit sharing in 1983 (Blasi 1990). The distribution of deferred profit sharing and ESOPs varies substantially across economic sectors (Kruse 1991). The prevalence is high in manufacturing and finance, insurance, and real estate and low in construction and services. Kruse estimates that profit sharing plans are adopted by $20-28$ percent of U.S. companies and that the percentage is higher in nonunion firms.

Cash profit sharing, apparently, plays a smaller role in the United States than in Germany compared to all PS schemes. This finding can be interpreted in the sense that American PS schemes tend to favor either long run incentives for greater effort and/or make use of the offered tax exemptions. The $401(\mathrm{k})$ plans have a roughly similar legal basis as PS in Germany, i.e. the Property Development Act in conjunction with property promotion possibilities of the Income Tax Act. While a majority of German PS schemes use the tax and social security exemptions offered by these laws, the $401(\mathrm{k})$ plans, evidently, are not widely spread in the U.S. One explanation could be that alternative PS plans in the U.S. are more attractive concerning the policies and tax exemptions the government has devised.

Both deferred profit sharing plans and ESOPs provide incentives to employees after a long duration of employment. This form of PS could strengthen employees' loyalty to the firm and help to establish a long-term relationship between worker and firm. Alternative explanations of this observed pattern of PS may be suggested. One hypothesis is that deferred plans and ESOPs are a substitute for privately provided pension plans since they are subject to less restrictive government regulations. If this interpretation is valid it could explain, too, why there is no German counterpart to deferred plans and ESOPs. Pension plans in the German social security system are (still) fairly generous and additional pensions provided by firms are rare compared to the U.S. Thus, German firms, interested in PS, do not consider the trade-off between expensive and heavily regulated private pension plans and deferred PS schemes, they focus primarily on the incentive effects of PS plans. After a possible future retrenchment of old-age benefits in Germany an increase in deferred PS plans could be expected.

A second hypothesis for the prevalence of deferred plans and ESOPs in the U.S. is that they tend to make compensation more flexible. "The two pillars of the American compensation system are collapsing: the pure fixed wage system and the pure fixed retirement system" (Blasi and Kruse 1991: 131). This movement toward a more flexible compensation could represent a response to severe demand shocks during the last decade. An analogous reaction on the part of German firms should be expected. However, due to the smaller importance of privately funded pensions (compared to the U.S.) this strategy is not very attractive. German firms react to demand shocks first by reducing other fringe benefits and second by reducing work time and thirdly by dismissing workers.

Unions in both countries traditionally exhibited a negative attitude toward PS. Company-based unions, which predominate in the U.S., however, might be more 


\section{PROFIT SHARING IN GERMAN FIRMS}

inclined to cooperate with management on PS than the national unions in Germany organizing labor mainly in firms without PS. Deferred profit sharing may offer employees an additional voice option to unions as the traditional collective voice of workers. A coexistence of deferred PS and unions may lead to a mutual reinforcement of the two voice options and consequently to a positive impact on firm's performance. Consequently, it could be expected that unions will change their stance with respect to PS more rapidly than their German counterparts.

\section{PROFIT SHARING OF EMPLOYEES: HYPOTHESES}

The theoretical analysis of profit sharing must first investigate the reasons why some firms adopt profit sharing and why the majority of firms is opposed to this form of compensation. Second, the economic effects of profit sharing have to be scrutinized. It is evident that economic effects of profit sharing have an impact on the decision to implement this form of compensation. In a first step an isolated investigation of determinants and effects might be admissible, in a second step the interdependence between determinants and effects has to be fully considered.

Concerning the characteristics that differ between PS and non-PS firms and the effects of profit sharing, the theoretical analysis is characterized by a high degree of uncertainty: each hypothesis $(\mathrm{H})$ can be answered by an alternative hypothesis $(\mathrm{A})$. In the sequel, this is illustrated by a juxtaposition of some selected hypotheses which focus on institutional aspects and are formulated from the perspective of the firms' management and the work force.

\section{Mode of Payment}

H1 Profit sharing plans might include a monthly or annual cash payment calculated according to an ex ante stipulated formula. Observers frequently assume that these schemes provide incentives for greater effort than sharing plans without a cash component and distribution formula. An annual payment of a bonus makes it easy to understand that remuneration and firm performance are tied. The profit share of the work force is predictable due to the ex ante negotiated and rigid formula of distribution. In addition, a cash payment compared to a participation via employee stock ownership is not subject to both uncertainties, i.e. fluctuations of the size of the bonus and of the stock price.

A1 Employee stock ownership as a form of profit sharing facilitates a long-term relationship between worker and firm which increases loyalty to the firm. A sense of co-ownership will emerge strengthening the identification with the objectives of management and reducing conflicts and dissension. 


\section{Alternative Incentives}

H2 Profit sharing will be selected as an incentive in conditions precluding piece rates, efficiency wages, and group incentive plans. These conditions prevail if a majority of workers produces a nonstandardized output and is involved in the development of new products and the improvement of products. An introduction of profit sharing can be expected when workers exert a substantial impact on the overall performance of the firm.

A2 Workers differ with respect to their reactions to incentives. A complex system of incentives including profit sharing as one component might be more expensive and efficient than a pure profit sharing scheme. If the firm's revenue permits a combination of incentives this combination could be advantageous in the long run.

\section{Firm Size}

H3 If profit sharing generates an incentive effect it should prevail in small and medium-sized firms, since the incentives will be barely diluted. Additionally, if competition is higher for small and medium-sized firms than for large firms and the former are confronted with a widely fluctuating product demand, profit sharing could in those circumstances increase the flexibility of human resource management.

A3 In large firms workers tend to be heterogeneous. As a consequence, it proves difficult to satisfy the diverse interests with a single incentive plan. Due to the division of labor and team production large firms frequently are rather profitable and dispose of the financial resources required for a combined scheme of incentives, including profit sharing.

\section{Unions}

H4 Unions might consider profit sharing as an opportunity to gain influence and to have access to a broad spectrum of entrepreneurial decisions. The reason is that groups participating in profits should have an impact on the major determinants of profits. An increasing strength of unions in a firm could consequently raise the probability of introducing a profit sharing scheme.

A4 For two reasons a negative correlation is predicted between profit sharing and unionization. Traditionally, unions have opposed profit sharing, although this negative attitude has been modified recently. Profit sharing can be adopted explicitly to deter unionization and to undermine the relationship between workers and unions. 


\section{Works Councils}

H5 A works council as an institution is legally independent from unions, de facto however, close relationships exist. If A4 is valid and works councils support the goals of unions, they will oppose the adoption of profit sharing. Furthermore, in firms with profit sharing, works councils could be coerced to accept an uneasy mediating position between capital and labor entailing a loss of confidence of the work force.

A5 Individual contracts between management and workers or collective contracts between management and the works council can constitute the legal basis for the adoption of profit sharing. A collective contract is frequently recommended due to legal arguments and for reasons of motivation. The works council can gather the information to monitor and supervise the adoption and execution of a profit sharing scheme, disseminate complete and reliable information to the work force, thus supporting the goals the firm wishes to attain with profit sharing.

\section{Regions}

H6 In rapidly growing regions many firms will be exceptionally profitable. For these firms it is easier than for their counterparts in stagnant or declining regions to adopt profit sharing. Regional competition in the labor market might coerce them to pursue this strategy.

A,6 In stagnant or declining regions, e.g. the New German Lander, profit sharing and a low base wage instead of a higher fixed wage might be an advisable strategy to strengthen future competitiveness.

$\mathbf{A}_{2} 6$ Worker preferences for a fixed compensation or for a compensation package including profit sharing might vary between regions. In some regions workers with a potential owner psychology might predominate.

$A_{3} 6$ The regional impact on the frequency of profit sharing plans should be limited after controlling for labor market conditions, sectors, firm size, qualification of workers, and degree of unionization, since firms face basically similar problems of motivation and fexibility regardless of location.

\section{Productivity}

H7 A firm's productivity can be enhanced by adopting profit sharing. In firms with financial participation workers' effort exceeds the intensity in firms paying fixed wages, since, with a remuneration that is entirely independent of individual performance, a utility- or income-maximizing worker will not have incentives for 
effort. In addition, profit sharing tends to generate a mutual control and supervision as workers would participate both in gains from higher effort and losses from shirking of their colleagues.

A7 Individual effort has only a negligible impact on the firm's overall performance. Profit sharing will not elicit higher effort, since each worker selects a freerider strategy and expects that the improved performance of co-workers has a positive impact on profits.

\section{Nonpecuniary Participation}

H8 Positive productivity effects of PS according to $\mathrm{H} 7$ can be augmented by a combination of PS with employee involvement in decision making (nonpecuniary participation, codetermination). Many dimensions of effort, such as working harder and more precisely, accepting flexible time schedules and a variety of jobs, taking initiative, and being responsible for material and maintenance, are difficult to observe or unobservable. Additionally, it may be impossible to allocate output to individual levels of effort. Therefore, due to free-riding the incentive effects of PS may be not sufficient to compensate for the costs. Furthermore, possible compensation of employees for risk taking via profit sharing may reduce net profits in the firm.

Nonpecuniary participation is needed as a complement to improve the emergence of a company spirit, to strengthen responsibility and flexibility, to improve the flow of information, and the acceptance of decisions. The effects could be a reduction of turnover costs ind absenteeism, of costs of on-the-job training, and a decreased willingness to withhold information from management. In firms where PS and participation are combined, the attitude toward new technologies is more positive than without participation, and the horizontal control of peers is strengthened. This indirect control decreases costs compared with traditional hierarchical control of supervisors.

A8 The combination of PS with participation is dominated by pure PS schemes and by the traditional fixed wage system, respectively. If workers participate not only in profits, but also in decision making, management and capital are not so careful as usual; they feel restricted in their property rights. Employees tend to prefer short-run decisions maximizing the contracted profit share and reducing investment. The combination of PS and nonpecuniary participation increases the costs and time of attaining agreements because additional decision makers besides management are involved.

In the following empirical part of this chapter the conflicting hypotheses about PS will be investigated. 


\section{DATA}

The data of our investigation, which were obtained from firms, are based on two sources. First, the population is composed of firms in the manufacturing sector of Lower Saxony and Baden-Württemberg with five or more employees. A random sample stratified according to four firm size classes was drawn in the two federal states $(n=206)$. The interviews were conducted by Infratest Sozialforschung (Munich) using our questionnaire in the period October 1990 to January 1991. For 1989 , data on 103 firms are available. The data include information on a broad spectrum of issues such as production, marketing, personnel, costs, revenue, and profits. The majority of the firms (91) had no profit sharing scheme. These 91 firms constitute our control group. For the 12 profit sharing firms additional information was gathered about the year of adoption, the proportion of eligible and participating employees and the amount of profits distributed to the participants.

Second, the Institute for Quantitative Economic Research (IQW, University of Hannover) interviewed 33 firms in Lower-Saxony and Baden-Württemberg, which had adopted profit sharing schemes. The interviews were conducted in the period April 1991 to June 1992. We used the questionnaire that forms the basis of our first data source. However, addicional questions concerning details of the sharing system and employees' participation in decision making were included. The data also refer to 1989.

\section{EMPIRICAL ANALYSIS}

\section{Descriptive Statistics}

\section{PS Firms Versus Non-PS Firms and Comparison of PS Firms}

As Table 7.2 demonstrates PS firms are on average larger than their non-PScounterparts. More than 70 percent of them has a work force of at least 200 employees. The proportion of firms of that size ( $\geq 200$ employees) in the subsample of non-PS firms is less than 20 percent. This finding contradicts $\mathrm{H} 3$, which emphazises the perceptibility of bonus payments as a necessary condition for the intended incentive effects of PS. Sharing firms tend to export more than non-PS firms ( 30 vs. 20 percent of sales), and they are more successful in the introduction of new or recently improved products ( $86 \mathrm{vs.} 48$ percent of the relevant firms). In addition, they are more likely to hold parents.

The skill composition of the labor force within the two subsamples differs systematically. The proportions of white collar and highly qualified workers (with a university degree) in firms with PS exceed those ratios in non-PS firms by 40 percent and 45 percent, respectively. The probability of the existence of a works council is higher in sharing firms, the degree of unionization is almost identical. The preceding arguments could have the implication that the accumulation of specific human capital facilitates the production process and that information sharing between employees and management is improved. 
VIVIAN CARSTENSEN, KNUT GERLACH, OLAF HUBLER

Table 7.2 Descriptive Staristics of PS and Non-PS Firms and Regional Comparisons of PS Firms: Number of Observations (N), Means, Standard Deviations, and Tests of Differences Between Means ( $\mathrm{t}$-statistics)

\begin{tabular}{|c|c|c|c|c|c|c|c|}
\hline & \multicolumn{3}{|c|}{$\begin{array}{l}\text { Firms with } \\
\text { Profit Sharing }\end{array}$} & \multicolumn{3}{|c|}{$\begin{array}{l}\text { Firms without } \\
\text { Profit Sharing }\end{array}$} & \multirow[b]{2}{*}{$t^{b}$} \\
\hline & $N^{a}$ & Mean & $\begin{array}{l}\text { Standard } \\
\text { Deviation }\end{array}$ & $N$ & Mean & $\begin{array}{l}\text { Standard } \\
\text { Deviation }\end{array}$ & \\
\hline FSIZEC & 41 & 2.54 & 0.78 & 87 & 1.67 & 0.80 & $5.85^{\circ}$ \\
\hline INNOV & 43 & 0.86 & 0.35 & 86 & 0.48 & 0.50 & $5.04^{\circ}$ \\
\hline EXPORT & 38 & 31.31 & 26.43 & 84 & 21.19 & 24.52 & $2.00^{\circ}$ \\
\hline PPE & 31 & 57.52 & 99.83 & 62 & 49.19 & 52.80 & 0.41 \\
\hline PROD & 37 & 149.42 & 145.63 & 77 & 103.98 & 61.56 & 0.76 \\
\hline CAPINT & 36 & 64.96 & 86.46 & 69 & 36.26 & 46.78 & 1.38 \\
\hline WOCOUN & 44 & 0.84 & 0.37 & 86 & 0.45 & 0.50 & $4.99^{\circ}$ \\
\hline PWU & 35 & 31.55 & 27.68 & 46 & 30.58 & 36.12 & 0.14 \\
\hline SKILLED & 38 & 0.09 & 0.10 & 77 & 0.05 & 0.07 & $2.30^{\circ}$ \\
\hline WCOL & 41 & 0.40 & 0.23 & 86 & 0.28 & 0.17 & $3.20^{\circ}$ \\
\hline WPT & 38 & 0.07 & 0.05 & 80 & 0.07 & 0.10 & 0.03 \\
\hline APPR & 40 & 0.06 & 0.07 & 78 & 0.06 & 0.08 & 0.02 \\
\hline DPPS & 43 & 0.77 & 0.37 & 84 & 0.48 & 0.50 & $3.42^{\circ}$ \\
\hline DTREX & 40 & 0.95 & 0.22 & 86 & 0.53 & 0.50 & $6.45^{\circ}$ \\
\hline WPE & 32 & 58.64 & 14.15 & 69 & 50.21 & 17.84 & 1.81 \\
\hline DEFFWAGE & 43 & 0.93 & 0.26 & 71 & 0.80 & 0.40 & $2.07^{\circ}$ \\
\hline DSEN & 42 & 0.67 & 0.47 & 71 & 0.52 & 0.50 & 1.54 \\
\hline MCUST & 43 & 1.14 & 0.94 & 86 & 1.86 & 0.46 & $4.71^{\circ}$ \\
\hline SHARE & 36 & 34.75 & 24.92 & 73 & 41.84 & 31.08 & 1.29 \\
\hline $\mathrm{APC}$ & 44 & 2.88 & 1.66 & 86 & 3.64 & 1.58 & $2.49^{\circ}$ \\
\hline FEXP & 44 & 4.11 & 0.75 & 83 & 4.45 & 0.70 & $2.42^{\circ}$ \\
\hline IPROM & 43 & 1.76 & 0.57 & 81 & 2.30 & 0.83 & $4.26^{\circ}$ \\
\hline IPS & 43 & 2.07 & 0.70 & 80 & 2.53 & 1.02 & $2.91^{\circ}$ \\
\hline IPART & 43 & 1.63 & 0.69 & 83 & 2.19 & 0.85 & $4.02^{\circ}$ \\
\hline
\end{tabular}

Firms opting for profit sharing incur higher training expenditures than their nonsharing counterparts: financial support is guaranteed by almost all PS firms, and by only half of the non-PS firms. Additionally, the existence of a company pension system is more likely. Encouragement of further training supplemented by deferred compensations, i.e. pensions and long-term contracts, can be interpreted as the workers' participation in the costs and returns of firm specific human capital. This directly supports the rent-sharing hypothesis of long-term employment (Hashimoto 1979). The goal is to reduce quits and to attract or to tie qualified employees to the firm. PS firms pay bonuses in addition to regular wages and seem to use bonus payments and efficiency wages as a compensation package ( 10 percent level).

The following variables depict subjective assessments of the management of firms and, therefore, may be biased. PS firms tend to be relatively independent of 
Table 7.2 (Continued)

\begin{tabular}{|c|c|c|c|c|c|c|c|}
\hline \multirow[b]{3}{*}{ PWU } & \multicolumn{3}{|c|}{$\begin{array}{l}\text { PS Firms in } \\
\text { Lower Saxony }\end{array}$} & \multicolumn{3}{|c|}{$\begin{array}{c}\text { PS Firms in } \\
\text { Baden-Württemberg }\end{array}$} & \multirow{2}{*}{$t^{b}$} \\
\hline & \multicolumn{6}{|c|}{ Fimm-Related Variables } & \\
\hline & 20 & 39.87 & 28.29 & 15 & 20.47 & 23.35 & $2.22^{\circ}$ \\
\hline WPT & 24 & 0.05 & 0.04 & 14 & 0.09 & 0.06 & $2.49^{\circ}$ \\
\hline \multirow[t]{2}{*}{ APPR } & 24 & 0.08 & 0.08 & 16 & 0.04 & 0.03 & $2.19^{\circ}$ \\
\hline & \multicolumn{7}{|c|}{ PS-Related Variables } \\
\hline PSYEARS & 24 & 12.88 & 9.62 & 15 & 14.07 & 11.11 & 0.34 \\
\hline ELIG & 24 & 77.50 & 33.84 & 19 & 88.63 & 22.25 & 1.30 \\
\hline INVOL & 25 & 60.20 & 38.34 & 19 & 75.63 & 29.49 & 1.51 \\
\hline CAPE & 19 & 5.42 & 10.51 & 12 & 8.14 & 16.77 & 0.50 \\
\hline HIER & 19 & 4.89 & 1.19 & 14 & 4.00 & 1.11 & $2.21^{\circ}$ \\
\hline PSPW & 22 & 0.04 & 0.04 & 12 & 0.08 & 0.09 & 1.51 \\
\hline PSPE & 22 & 1.75 & 2.18 & 12 & 2.84 & 3.15 & 1.07 \\
\hline PSPP & 20 & 0.04 & 0.05 & 9 & 0.06 & 0.06 & 0.96 \\
\hline PSPIN & 22 & 1.94 & 2.25 & 12 & 3.19 & 3.02 & 1.25 \\
\hline FPART & 18 & 2.00 & 0.97 & 14 & 1.79 & 0.89 & 0.65 \\
\hline DDPE & 19 & 0.74 & 0.45 & 14 & 0.64 & 0.49 & 0.56 \\
\hline DDPWC & 16 & 0.93 & 0.25 & 13 & 0.61 & 0.51 & $2.10^{\circ}$ \\
\hline DPROD & 19 & 0.63 & 0.49 & 14 & 0.29 & 0.47 & $2.04^{\circ}$ \\
\hline DSOLID & 19 & 0.53 & 0.51 & 14 & 0.86 & 0.36 & $2.17^{\circ}$ \\
\hline DFLUCT & 19 & 0.37 & 0.49 & 14 & 0.57 & 0.51 & 1.14 \\
\hline DABSENT & 19 & 0.26 & 0.45 & 14 & 0.43 & 0.51 & 0.96 \\
\hline DLEGAL & 19 & 0.21 & 0.42 & 14 & 0.36 & 0.49 & 0.89 \\
\hline DFAIR & 19 & 0.84 & 0.38 & 14 & 0.85 & 0.36 & 0.12 \\
\hline WATTID & 17 & 0.53 & 0.51 & 13 & 0.46 & 0.52 & 0.36 \\
\hline EPROD & 19 & 0.42 & 0.51 & 14 & 0.14 & 0.37 & 1.84 \\
\hline ESOLID & 19 & 0.42 & 0.51 & 14 & 0.71 & 0.47 & 1.71 \\
\hline EFLUCT & 19 & 0.16 & 0.38 & 14 & 0.29 & 0.47 & 0.84 \\
\hline
\end{tabular}

Notes.

- Several questions were nor answered by all firms. Therefore, for each variable the number of observations is documented.

bSignificant differences between the two subgroups ( $\alpha=0.05$, normal distribution) are marked by an

major customers compared to their nonsharing counterparts, and the reported assessment of actual profits (per sales) in comparison with profits of competitors is more favorable.

Firms that opt for profit sharing do nor consider the work experience of applicants as such a strong signal for ability as their nonsharing counterparts. The assessment of the long-run effects of important incentives differs systematically. While firms with PS rely, first, on the opportunity of promotion, second, on the introduction or improvement of sharing schemes, and, third, on a high degree of 
employee participation in decision making as adequate means to motivate workers, non-PS firms are rather pessimistic concerning these factors.

A regional split of the sample of PS firms ( $1=$ Lower Saxony, $0=$ BadenWürttemberg) does not produce strong differences (Table 7.2).' There is some evidence that relatively more part-time workers and apprentices are employed in PS firms of Baden-Württemberg compared to Lower Saxony. PS firms in the latter federal state face a higher degree of unionization. Expected productivity gains are mentioned more frequently as a reason for introducing PS by firms in Lower Saxony, while the improvement of solidarity between management and workers as well as among employees is an important cause of introduction of PS in firms of Baden-Württemberg. In addition, Lower Saxonian PS firms are organized more hierarchically than their counterparts in Baden-Württemberg.

In Table 7.3 the sample of PS firms is split into the two subgroups of

(a) firms that have introduced the sharing scheme prior to the Property Development Act in $1984(\mathrm{D} 84=0)$ and

(b) firms that opted for profit sharing after the enactment (D84 $=1$ ).

No differences are derected according to the firm-related variables (not all presented in the table). The industry-specific variable MARKUP, which represents the inverse ranking of the industry-specific ratio of value added minus labor costs to sales, is larger in the second group. Gross profits in industries where PS became popular after the enactment in 1984 seem to exceed those in traditional sharing industries.

The PS-related variables in the two subsamples are almost identical with the exception of the proportion of participating employees (INVOL), the amount of PS per (employed) worker (PSPE), and the ratio of PS to wages (PSPW). Participation of employees (INVOL) is stronger in firms belonging to subsample (a). There is, however, no evidence for a higher eligibility in firms which adopted PS before 1984. The difference of PSPE and PSPW between the two groups diminishes if the amount of PS per participating employee (PSPIN) is considered. These results in conjunction with insignificant differences in the remaining PSrelated variables in Table 7.3 favor the hypotheses that possible determinants and effects of PS are independent of tax subsidies.

\section{Simple Correlations of PS}

In Table 7.4 correlations are documented between

1 worker's share in profits (PSPP),

2 ratio of profit sharing to wages (PSPW), and

3 level of profit sharing per employee (PSPE)

on the one hand and

(a) profits per employee (PPE),

(b) firm size (FSIZE), and 


\section{PROFIT SHARING IN GERMAN FIRMS}

Table 7.3 Comparisons of PS Firms with Introduction of the Scheme prior to the Property Development Act in 1984 (D84=0) and after the Enactment (D84 = 1). Number of Observations (N), Means, Standard Deviations, and Tests of Differences between Means (t-statistics)

\begin{tabular}{|c|c|c|c|c|c|c|c|}
\hline & \multicolumn{3}{|c|}{$\begin{array}{l}\text { PS Introduction } \\
\text { before } 1984\end{array}$} & \multicolumn{3}{|c|}{$\begin{array}{l}\text { PS Introduction } \\
\text { after } 1984\end{array}$} & \multirow[b]{2}{*}{$t^{b}$} \\
\hline & $N^{a}$ & Mean & $\begin{array}{l}\text { Standard } \\
\text { Deviation }\end{array}$ & $N$ & Mean & $\begin{array}{l}\text { Standard } \\
\text { Deviation }\end{array}$ & \\
\hline & \multicolumn{6}{|c|}{ Firm-related Variables } & \\
\hline FSIZE & 25 & 848.64 & $1,016.32$ & 19 & $3,855.52$ & $14,988.27$ & 0.87 \\
\hline EXPORT & 23 & 34.39 & 27.08 & 18 & 29.28 & 24.92 & 0.63 \\
\hline MARKUP & 25 & 5.72 & 3.12 & 20 & 7.35 & 3.03 & 1.76 \\
\hline PWU & 23 & 34.00 & 28.51 & 13 & 31.00 & 29.45 & 0.30 \\
\hline WPT & 25 & 0.07 & 0.05 & 17 & 0.08 & 0.07 & 0.44 \\
\hline \multirow[t]{2}{*}{ APPR } & 25 & 0.05 & 0.04 & 18 & 0.09 & 0.09 & 1.57 \\
\hline & \multicolumn{6}{|c|}{ PS-related Variables } & \\
\hline ELIG & 25 & 83.00 & 42.38 & 20 & 69.00 & 38.39 & 1.16 \\
\hline INVOL & 25 & 76.72 & 31.19 & 20 & 52.95 & 38.39 & $2.29^{\circ}$ \\
\hline CAPE & 19 & 7.83 & 15.29 & 13 & 4.87 & 8.50 & 0.70 \\
\hline HIER & 19 & 4.63 & 1.30 & 14 & 4.36 & 1.15 & 0.63 \\
\hline PSPW & 23 & 0.09 & 0.13 & 16 & 0.03 & 0.05 & $2.27^{\circ}$ \\
\hline PSPE & 24 & 4.52 & 7.71 & 17 & 0.96 & 1.21 & $2.22^{\circ}$ \\
\hline PSPP & 17 & 0.05 & 0.05 & 15 & 0.03 & 0.05 & 1.56 \\
\hline PSPIN & 24 & 5.65 & 8.50 & 17 & 4.37 & 6.74 & 0.52 \\
\hline FPART & 18 & 1.93 & 0.67 & 14 & 1.74 & 0.77 & 0.73 \\
\hline DDPE & 19 & 0.74 & 0.45 & 14 & 0.86 & 0.36 & 0.82 \\
\hline DDPWC & 17 & 0.82 & 0.39 & 12 & 0.92 & 0.29 & 0.70 \\
\hline DPROD & 19 & 0.47 & 0.51 & 14 & 0.50 & 0.52 & 0.14 \\
\hline DSOLID & 19 & 0.74 & 0.45 & 14 & 0.57 & 0.51 & 0.98 \\
\hline DFLUCT & 19 & 0.42 & 0.51 & 14 & 0.50 & 0.52 & 0.44 \\
\hline DABSENT & 19 & 0.32 & 0.48 & 14 & 0.36 & 0.49 & 0.24 \\
\hline DLEGAL & 19 & 0.26 & 0.45 & 14 & 0.29 & 0.47 & 0.14 \\
\hline DFAIR & 19 & 0.74 & 0.45 & 14 & 1.00 & 0.00 & - \\
\hline WATTID & 18 & 0.56 & 0.51 & 12 & 0.42 & 0.52 & 0.73 \\
\hline EPROD & 19 & 1.53 & 0.51 & 14 & 1.71 & 0.47 & 1.08 \\
\hline ESOLID & 19 & 1.16 & 0.38 & 14 & 1.21 & 0.43 & 0.40 \\
\hline EFLUCT & 19 & 1.58 & 0.51 & 14 & 1.71 & 0.47 & 0.78 \\
\hline
\end{tabular}

Notes:

2 Several questions were not answered by all firms. Therefore, for each variable the number of observations is documented.

${ }^{\mathrm{b}}$ Significant differences between the two subgroups ( $\alpha=0.05$, normal distribution) are marked by an asterix. 
Table 7.4 Simple Correlations between Profit Sharing Variables and Firm-related Variables: Coefficients, Level of Significance (One-Tailed in Parentheses), Number of Cases

\begin{tabular}{|c|c|c|c|c|}
\hline & $P S P P$ & $P S P E$ & PSPW & PSYEARS \\
\hline \multirow[t]{2}{*}{ PPE } & $\begin{array}{c}-0.189 \\
(0.135)\end{array}$ & $\begin{array}{c}0.523 \\
(0.001)\end{array}$ & $\begin{array}{c}0.291 \\
(0.038)\end{array}$ & $\begin{array}{c}0.112 \\
(0.252)\end{array}$ \\
\hline & 29 & 36 & 38 & 38 \\
\hline \multirow[t]{2}{*}{ FSIZE } & $\begin{array}{c}0.218 \\
(0.128)\end{array}$ & $\begin{array}{c}0.183 \\
(0.148)\end{array}$ & $\begin{array}{c}0.177 \\
(0.151)\end{array}$ & $\begin{array}{c}0.297 \\
(0.033)\end{array}$ \\
\hline & 29 & 36 & 36 & 39 \\
\hline \multirow[t]{2}{*}{ PSYEARS } & $\begin{array}{c}0.313 \\
(0.050)\end{array}$ & $\begin{array}{c}0.499 \\
(0.001)\end{array}$ & $\begin{array}{c}0.529 \\
(0.000)\end{array}$ & $\begin{array}{r}1 \\
(0)\end{array}$ \\
\hline & 29 & 36 & 36 & 39 \\
\hline \multirow[t]{2}{*}{ D84 } & $\begin{array}{c}-0.278 \\
(0.072)\end{array}$ & $\begin{array}{c}-0.316 \\
(0.036)\end{array}$ & $\begin{array}{c}-0.313 \\
(0.032)\end{array}$ & $\begin{array}{c}-0.735 \\
(0.000)\end{array}$ \\
\hline & 29 & 36 & 36 & 39 \\
\hline \multirow[t]{2}{*}{ PROD } & $\begin{array}{c}-0.186 \\
(0.168)\end{array}$ & $\begin{array}{c}0.488 \\
(0.002)\end{array}$ & $\begin{array}{c}0.375 \\
(0.014)\end{array}$ & $\begin{array}{c}0.087 \\
(0.303)\end{array}$ \\
\hline & 29 & 34 & 34 & 37 \\
\hline \multirow[t]{2}{*}{ ABSENT } & $\begin{array}{c}-0.326 \\
(0.042)\end{array}$ & $\begin{array}{c}-0.332 \\
(0.024)\end{array}$ & $\begin{array}{c}-0.306 \\
(0.035)\end{array}$ & $\begin{array}{c}-0.233 \\
(0.077)\end{array}$ \\
\hline & 29 & 36 & 36 & 39 \\
\hline FPART & $\begin{array}{c}0.276 \\
(0.213) \\
21\end{array}$ & $\begin{array}{l}0.269 \\
(0.087) \\
27\end{array}$ & $\begin{array}{c}0.237 \\
(0.118) \\
27\end{array}$ & $\begin{array}{c}0.075 \\
(0.539) \\
28\end{array}$ \\
\hline DDPE & $\begin{array}{c}0.099 \\
(0.331) \\
22\end{array}$ & $\begin{array}{l}0.242 \\
(0.107) \\
28\end{array}$ & $\begin{array}{l}0.239 \\
(0.110) \\
28\end{array}$ & $\begin{array}{l}0.053 \\
(0.394) \\
28\end{array}$ \\
\hline DDPWC & $\begin{array}{l}0.236 \\
(0.173) \\
18\end{array}$ & $\begin{array}{l}0.266 \\
(0.105) \\
24\end{array}$ & $\begin{array}{c}-0.177 \\
(0.180) \\
29\end{array}$ & $\begin{array}{l}0.062 \\
(0.385) \\
25\end{array}$ \\
\hline DMAINT & $\begin{array}{c}0.621 \\
(0.001) \\
22\end{array}$ & $\begin{array}{l}0.246 \\
(0.103) \\
28\end{array}$ & $\begin{array}{c}0.410 \\
(0.015) \\
28\end{array}$ & $\begin{array}{c}0.249 \\
(0.096) \\
29\end{array}$ \\
\hline DFLUCT & $\begin{array}{c}0.657 \\
(0.000) \\
22\end{array}$ & $\begin{array}{c}0.440 \\
(0.010) \\
28\end{array}$ & $\begin{array}{l}0.569 \\
(0.001) \\
28\end{array}$ & $\begin{array}{l}0.298 \\
(0.058) \\
29\end{array}$ \\
\hline DABSENT & $\begin{array}{l}0.288 \\
(0.097) \\
22\end{array}$ & $\begin{array}{l}0.336 \\
(0.040) \\
28\end{array}$ & $\begin{array}{l}0.474 \\
(0.005) \\
28\end{array}$ & $\begin{array}{l}0.346 \\
(0.033) \\
29\end{array}$ \\
\hline DQUAL & $\begin{array}{l}0.167 \\
(0.230) \\
22\end{array}$ & $\begin{array}{l}0.415 \\
(0.014) \\
28\end{array}$ & $\begin{array}{l}0.370 \\
(0.026) \\
28\end{array}$ & $\begin{array}{l}0.313 \\
(0.050) \\
29\end{array}$ \\
\hline
\end{tabular}


(c) years since the adoption of the actual sharing system (PSYEARS) on the other hand.

In addition, correlations of these variables and important indicators of firm performance are reported. Finally, the relationship of various variables with employees' participation in decision making is considered (for a definition of the generated participation variables see Appendix).

The incumbents' share of profits (PSPP) as well as labor productivity (PROD) tend to decline with rising profits (10 percent level). Labor costs (excluding PSoutlay) are positively related to PSPP. No relationship exists berween PSPP and firm size, despite the fact that the largest profit shares are found only in firms which employ at least 200 workers. The correlation between PSYEARS and PSPP is positive. Large shares, however, are not correlated with high levels of participarion. Two of the reported determinants of PS (namely maintenance of machinery and reduction of fluctuation) are positively related to PSPP. Absenteeism decreases with PSPP.

Profit sharing per wages (PSPW) increases with higher labor productivity. Profits exceeding one monthly salary are distributed only in enterprises with high annual profits per employee (>DM10,000/worker), i.e. mainly in large firms. No support is found for the hypothesis that especially large firms with nonstandardized production have to pay perceptible (and therefore higher) bonuses in order to avoid the dilution of potential incentive effects of PS. Absenteeism, often regarded as an indicator of firm performance, declines with increased PS per wages. The number of years since the introduction (PSYEARS), and the fact of introducing the scheme prior to the enactment of the Property Development Act in 1984 are positively correlated with the amount of PSPW. This can be interpreted in the sense that voluntarily adopted schemes provide larger shares for employees (see also Table 7.3).

Profit sharing per employee (PSPE) is correlated with higher labor productivity and lower absenteeism. No relationship can be detected between firm size and PSPE; a long duration of the installed scheme, however, increases PSPE. Considering all PS firms, a proportion of 40 percent distributes DM500 per capita or less, which is exactly the legally subsidized amount. In the subsample of firms introducing PS after 1984, this proportion increases to 70 percent. In firms that introduced PS before 1984, PSPE exceeds DM500 with a proportion of 85 percent. These results suggest that firms and employees learn to improve PS as a system of mutual incentives for high effort and fairness. Furthermore, the duration of PS in the firm is negatively related to absenteeism and positively to firm size.

In a next step employee involvement in decision making is taken into consideration. On the whole, formal participation (for example, Quality Circles) is relatively widespread, especially in large enterprises. However, some firms that introduced PS after 1984 completely lack formal nonpecuniary participation. Correlation is found between the formal decision making of employees (FPART) and PSYEARS on the one hand and between the degree of the de facto nonpecuniary participation (DDPE, DDPWC) and PSYEARS on the other hand. 
Subsequently, intended effects of PS are considered. First, we look at the proportion of firms declaring that the specific variable had been a determinant for the introduction of PS. Second, these intended effects are compared with the real effect on those variables. The responses concerning the variables are subjective assessments by management and these may differ from the objective facts. About 50 percent reported productivity improvement as one reason for the introduction of PS. The goal of improving solidarity is reported by 67 percent, and 85 percent of the firms are interested in fairness. About 55 percent mentioned the recruitment of highly qualified applicants as a reason for introducing PS schemes. Legal subsidies did not play an important role ( 27 percent). For the firms mentioning these specific variables as determinants, it was analyzed whether the envisioned improvements had materialized. For 55 percent solidarity is improved, 30 percent report higher productivity, and 21 percent reduced fluctuation. These determinants and effects are correlated with PSYEARS. With a longer duration of the system the goals of decreasing absenteeism and of attraction of qualified applicants are reported more frequently. Firms with longer PSYEARS report lower degrees of absenteeism.

\section{Nonpecuniary Participation in Different PS Schemes}

A first impression of the conjunction of profit sharing and nonpecuniary participation on the basis of the institutional framework of the schemes is given in Figure 7.1. For each of the six typical schemes the duration of PS, the degree of workers' participation, i.e. de facto involvement of employees in substantial decisions like work- and job-organization (DPART4 $=3$ ), and the total number of sharing schemes within the firm are considered. The basis for the calculation of the number of schemes within a firm is not the number of firms, but the total number of schemes established in all firms. It is known how many firms have established a particular scheme of the six categories. However, additional pecuniary schemes might exist in the firm. The average number of these additional schemes constitutes the total number of sharing schemes. The duration of the system and the number of schemes installed can be interpreted as a proxy for the seriousness of entrepreneurs and management to participate workers in profits and decision making. The proportion of firms with de facto substantial participation in work organization and job related decisions indicates the degree of participation in the different PS schemes.

On average, the duration of participation in the firm's assets (11.6 years) is less than that of cash-based sharing systems (14.4 years), with the exception of employee stock ownerships, which last for almost 18 years. Apparently, the impact of the Property Development Act (1984) concerning the introduction of PS is negligible. The reduction of tax liabilities is particularly important in only two forms (PS with silent partnership and asset participation with loans). On average, these two systems were established more than three years prior to the enactment. The most obvious form of sharing-direct revenue or value-added 


\section{PROFIT SHARING IN GERMAN FIRMS}

sharing - has the longest tradition. The average duration of existence amounts to 22 years. As explained in the interviews, the paternalistically run companies often installed PS schemes because the entrepreneurs feel morally responsible for the work force.

In addition to the described pure systems a combination of different PS schemes is found in many firms. The most prevalent form is the link of asset participation with a cash-based system, where access to the cash component is based on the participation in the asset component. The high degree of participation in decision making (DPART4=3) is most often found in the scheme "firm performance bonus," where all eligible employees are obliged to participate. About 75 percent of these companies have substantial participation. More than 70 percent with asset participation and almost 70 percent of firms with employee stock ownership provide a substantial involvement of their workers in those decisions (DPART4 = 3).

Summarizing the descriptive results from Figure 7.1 it can be seen that combined systems of PS and nonpecuniary participation are typical in

1 large companies with employee stock ownership, with the risk of a potential dilution of incentive effects,

2 firms with schemes of asset participation taking the form of loans, and

3 enterprises, which base the calculation of distributable profit shares on a relative complex formula.

A first tentative investigation of PS may rely on comparisons of means, simple correlations, and descriptions. A more extended analysis, however, should not be based on these elementary statistics since they do not consider multicollinearity, interactions of job related variables, unobserved or omitted variables and the industrial relations context. In the subsequent econometric analysis the multivariate character of participation in PS and effects of PS is explicitly taken into account.

\section{Econometric Analysis_-Preliminary Results}

\section{PS Participation Functions}

The concept "determinants of PS" is explicitly avoided in favor of the term "PS participation functions." This is due to a limitation of our data set. The data refer to one period (1989) whereas a possible introduction of PS might have occurred in years prior to 1989. Therefore, it cannot be distinguished conclusively whether present characteristics of a firm had an impact on the past decision of introducing PS (since they remained stable for a number of years) or whether these characteristics have changed drastically in the time elapsed due to the adoption of PS or as a response to other factors affecting the firm. In that sense, PS participation or assignment functions point out the variables which differ between PS and non-PS firms. 
In the following, estimates of PS participation functions are presented. Different PS indicators are distinguished. First, a dummy variable

$$
D P S=\left\{\begin{array}{lc}
1 & \text { if } y^{*} \geq 0 \\
0 & \text { otherwise }
\end{array}\right.
$$

is employed as the unobserved endogenous variable $y^{*}$, which is an unobserved decision or objective variable of the firm introducing PS or continuing with the participation of employees in profits. A linear model is assumed to determine $y^{\circ}$

$$
y^{*}=z^{\prime} \beta+u
$$

where $y^{*}$ might be the change of productivity or profits due to PS and the components of vector $z$ are firms' characteristics that affect $y^{*}$. Three basic models are formulated (ML-estimates are presented in Table 7.5, columns 1-3). The first model is dominated by factors which describe the relative market position of the firms. The second model may be called "labor endowment model" and the third model is a pure sector dummy model. At a first glance the second model seems to be preferred due to pseudo- $\mathrm{R}^{2}, \mathrm{LRT}$, and t-ratios. However, a mixed model with elements from the other ones improves the approach. Statistical criteria favor specification (7). Except for the regional dummy and the metal sector dummy the signs of the coefficients are stable over the seven models.

Now we may confront our results with the preceding hypotheses. We start with some comments concerning influences that are not incorporated in the final model. Former studies (FitzRoy and Kraft 1985, 1986, 1987) have shown that the existence of a works council and a high degree of unionization have opposite effects on the probability of PS in a firm. The positive effect of the former variable also results in our investigation but the significance strongly depends on the model specification. We cannor find significant effects of unionization. Therefore, this variable is neglected in the following, but in all tested versions this coefficient remains positive. This is in accord with Palokangas's (1992) result that small unions prefer the ordinary wage system, while large unions are theorerically willing to make an agreement on PS. This means we cannot confirm the often mentioned negative effects of unions on PS schemes with our data. Neither hypothesis $\mathrm{H} 4$ nor the alternative $\mathrm{A} 4$ is unambiguously preferred.

Furthermore, we cannot reject the hypothesis that there does not exist a difference in the profit sharing behavior between the two considered German Lander Lower Saxony and Baden-Württemberg. The effect of the variable REGION ( $1=$ Lower Saxony) is insignificant. This speaks in favor of $\mathrm{A}_{3} 6$.

It should be emphasized that in PS firms the percentage of white collar workers and skilled workers is higher than in non-PS firms. Perhaps, in part the insignificance of the variable SKILLED stems from the high degree of multicollinearity with TREX. However, in specification (6) of Table 7.5, TREX is 


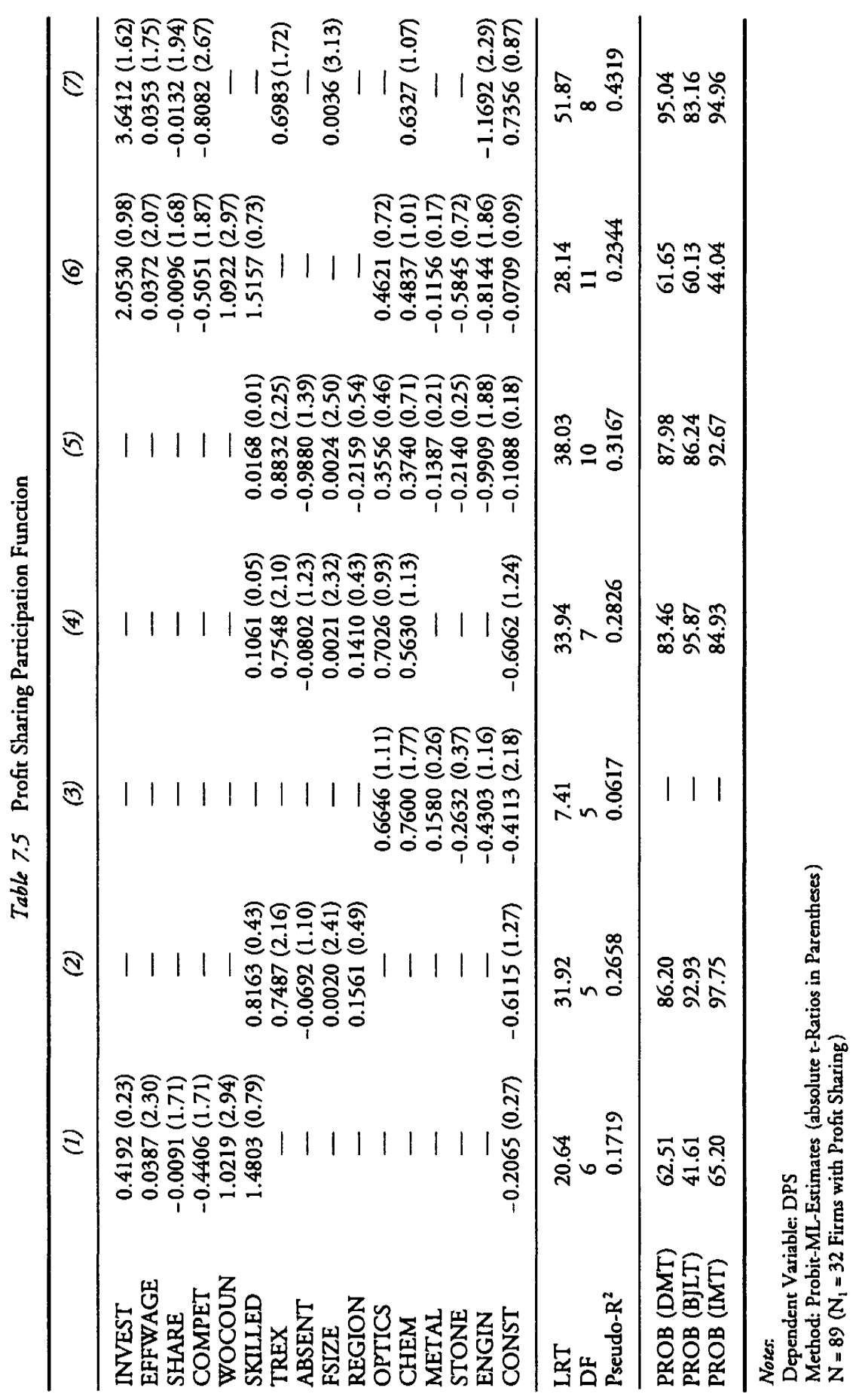


suppressed and the SKILLED effect remains insignificant, but multicollinearities with other variables are possible. The negative correlation between absenteeism and PS should be mentioned, although the causality is not unambiguous. Are workers participating in profits because they have a low degree of absenteeism, or does PS induce a reduction of absenteeism?

The importance of industries for PS is not obvious. In Hübler (1993) it is argued that high-wage sectors are more predestinated to introduce PS, because the free-rider problem does not seem to be so important. High sectoral wages-an indicator of efficiency wages-attract qualified and productive workers who are usually more satisfied with their jobs than other workers. This means there is a higher percentage of employees willing to work harder due to PS instead of improving the individual economic conditions by free-riding. But also historical aspects may explain sectoral differences.

In none of the seven models are the tested null hypotheses $\left(\mathrm{H}_{0}\right)$ rejected (homoscedasticity-DMT [Davidson and MacKinnon 1984]; normal distribution-BJLT [Bera et al. 1984]; correct specification-IMT [information matrix test in Orme's (1990) version]) as can be seen from the bottom of Table 7.5 ( $\mathrm{PROB}=100 \mathrm{P}\left(\mathrm{T} \geq \mathrm{T}_{\text {emp }} \mid \mathrm{H}_{0}\right)$ is the empirical significance level where $\mathrm{T}_{\text {emp }}$ is the empirical test statistic). The prob values of the tests (PROB) are much higher than the usual $100 a$ level. The pseudo- $R^{2}$ speaks in favor of model (7). And if we compare the LRT statistic of the saturated model (all mentioned variables in Table 7.5 are included in the estimation; the estimates are not presented in the tables; the LRT of this model is 54.69) with that of the seven models in Table 7.5 all other models except model (7) have to be rejected. With the exception of the two sectoral dummies and works council-see above-we can interpret the results in model (7) as follows:

1 With larger investments the probability that a firm shares the profits with its workers increases. The combination of high investments and PS indicates good economic conditions of the firm.

2 A high wage drift and the existence of PS are positively correlated. Hypothesis A2 is preferred to $H 2$. But we cannot say much about the causality. Do high wages induce high productivity and therefore the profit situation allows PS or does the argument run in the opposite direction or is the truth somewhere in between or do unobserved determinants exist which explain high wages and PS jointly? In Hübler (1993) unobserved abilities are mentioned as one possibility. Especially, we may expect this, if these abilities improve productivity due to the team work.

3 Firms with a high degree of competition avoid the introduction of PS. They fear that their cost situation deteriorates.

4 If firms have a high market share of their most important product, they are reluctant concerning PS. This seems to contradict (3). However, a high market share is not identical with a low degree of competition. Perhaps, there exist two firms' strategies, an output oriented strategy with the objective of high market 
shares and a labor input strategy in accordance with PS, which are not complementary.

5 Large training expenditures per employee are more often observed in PS than in non-PS firms. With an increasing qualification of the employees positive productivity effects due to PS are expected.

6 Large firms are more interested in PS than smaller ones. A3 is preferred to $\mathrm{H} 3$. This result is not in accordance with findings of FitzRoy and Kraft (1987). One explanation might be that the FitzRoy-Kraft sample contains only firms of medium size.

If we summarize the effects in model (7), apparently PS is more common in well-situated firms than in firms facing difficult economic conditions. We believe that PS is not an instrument to improve a firm's position. Firms with above-average profitability that do not share their rents with employees thus run the risk of demotivating workers and eroding the very basis of continuing success (FitzRoy 1990: 19). Our investigation does not support FitzRoy's and Kraft's conjecture that some firms start from a crisis situation to introduce team work and group incentives (FitzRoy and Kraft 1992; 219).

\section{Effects of PS}

Most empirical studies of profit sharing concentrate on productivity. FitzRoy and Kraft (1992) emphasize that a rare consensus has emerged: almost all empirical studies find a positive association between PS and productivity. However, the authors warn that the positive correlation might be an artifact. Unobserved factors such as quality of the management (Cablc and Wilson 1989) or job conditions can induce the relationship. Moreover, insufficient attention has been paid to the measurement of PS.

In Table 7.6 estimates of different productivity functions with some PS indicators are presented. Incorporated as control variables are the percentage of skilled employees (SKILLED), wages per employee (WPE), training expenditures per employee (TREX), capital intensity (CAPINT), a regional dummy (REGION), and sectoral dummies. Except for the regional variable, the signs of the coefficients are as expected. But the differences of the PS indicators should be stressed. If all firms are considered (upper part of Table 7.6) the following relationship results:

(a) If PS is measured by a dummy, positive significant productivity effects cannot be observed.

(b) Both the level of PS (LPS) and PS per employee (PSPE) induce positive and significant effects.

(c) The ratio of level of PS to total profits (PSPP) is negatively significantly correlated with productivity. 
VIVIAN CARSTENSEN, KNUT GERLACH, OLAF HÜBLER

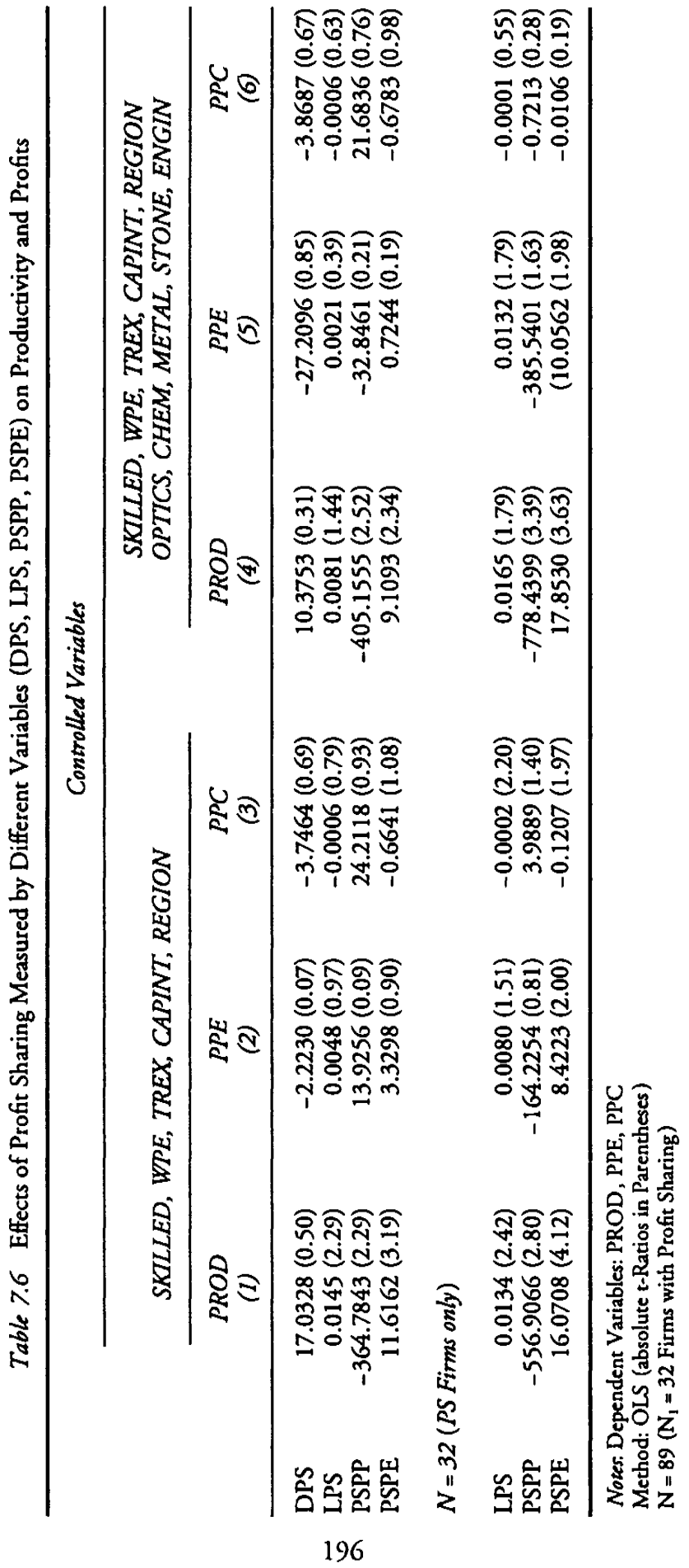


It might be argued that the neglect of firm size (FSIZE) induces the last result -in large firms incentives have to be stronger to induce the same productiviry effects, and productivity decreases with firm size. Therefore, the negative coefficient results in equations with PSPP. However, empirical investigations (not presented in Table 7.6) show that FSIZE has no productivity effects. But the question remains: why is productivity negatively correlated with PSPP and positively with the other PS-ratio (PSPE)? This is also confirmed with our data by simple correlation coefficients in Table $7.4 \quad(r(P R O D, P S P P)=-0.19$; $r(P R O D, P S P E)=0.49)$. The negative correlation seems to be an artifact, namely, PROD represents a relevant part in the denominator of PSPP (profits). Maximization of PROD is possibly not the major objective of the firms, they rather tend to maximize available (net)profits or net profits per employee (PPE) and per capital (PPC), respectively.

The upper part of Table 7.6 shows that PS neither significantly increases PPE nor PPC whereas a tendency of positive effects of LPS and PSPE on PPE and of negative effects on PPC can be found. Obviously, the positive PROD effects are compensated by the difference between gross and net profits. This outcome appears to be sensible. Otherwise, if PPE or PPC were significantly enlarged by PS, we would have to expect the introduction of a sharing system in all firms.

In the lower part of Table 7.6 the estimates are restricted to firms with PS. In these approaches the estimates are corrected for a potential sample selection bias by Heckman's (1979) suggestions of an additional artificial regressor (estimated hazard rate). However, the effects are not significant. The lower part of Table 7.6 also shows that within the subsample of PS firms the PPE and PPC effects of PS are more pronounced than within the total sample.

\section{PS and Nonpecuniary Participation}

As emphazised in the hypotheses, additional positive effects of PS on productivity may be expected by combining it with nonpecuniary participation (codetermination), and as Steinherr (1977) has demonstrated that whatever the objective function of the firm it requires fairly mild assumptions to render some profit sharing and participation in decision making always optimal. The expected advantages of employees' participation are improved channels of information, better conflict resolution, greater possibilities for acquiring on-the-job human capital from other workers, a more positive attitude toward the introduction of new technology. PS without participation of the employees can mean that the entrepreneur manipulates the calculation of profits so that employees feel distrustful and therefore PS has no real impact on productivity.

Participation can take many forms, and involves a multiplicity of institutional arrangements. Levine and Tyson (1990: 189) distinguish between consultative participation in work and workplace decisions, substantive participation in work and workplace decisions, and representative participation. In our investigation we separate between the degree of participation (DPART.) on the one hand, and 
formal participation (FPART) on the other hand. The former encompasses participation of works council in investment and rationalization (DPART1), in personnel decisions (DPART2), in pay issues (DPART3), and in job design (DPART4) with four different levels (0: no participation; 1: information; 2: consultation; 3: coresponsibility for the taking of decisions). FPART comprises the following items: quality control circles (QCC), teamwork (TW), joint labormanagement consultation committees (JLMC) measured as dummies. It is an open question how effective the different forms of participation are and the measurement problem is unsolved. The simplest way is using different binary variables with unit value if the firm is classified at the $j$ 'th participation level. Supposing that combined productivity effects between PS and participation exist, interaction variables should be constructed, and if the overall effect of participation is somehow to be gauged, a composite measure of the degree of participation in a given firm is also required. In the literature a weighted sum of the different dummies (Cable and FitzRoy 1980) or Guttman Scales (Cable 1988) are used. However, quantitative evaluations are extremely difficult because participation is usually associated with several other important changes in the workplace, the motivation to work and the reward structure. Therefore, we propose to construct a complete index using the instrument of principle component analysis where different variables are incorporated expressing the framework of the participation field. On the left hand part of Table 7.7 the results of the principal component analysis are presented where two factors are extracted. As can be seen from the factor loadings of the PS-participation framework variables on the two factors, the first factor can be interpreted as participation while the second factor describes PS. As firms' characteristics are usually highly multicollinear it seems sensible also to summarize the characteristics, using a factor analysis, although an interpretation of the factors is difficult as can be seen from the right hand part of Table 7.7.

A possible interpretation of the two extracted factors is the following. Factor 21 (F21) discriminates between new and old technology. The former is characterized by capital intensive firms with large expenditures for $R \& D$ and further training, with highly skilled workers producing a large value added per capita and obtaining high wages. These determinants have positive factor loadings on F21. Factor 22 (F22) separates between firms' scale of production-mass production vs. small series or single-piece production. The former can be described by large firms with numerous but unskilled workers, a high degree of unionization, a considerable amount of overtime work and strong export activities. This means F22 is positively loaded by mature industry production characteristics.

In Table 7.8 some estimates are presented where profit sharing and participation effects on productiviry are jointly considered. The specifications differ in measurement of PS and participation and in the controlled variables. The major results are the following: First, formal participation is only of minor relevance. Second, a high degree of participation generally does not exert positive effects on productivity. On the one hand, participation of employees is not effective while participation via works council is important in some fields. On the other hand, participation in job 


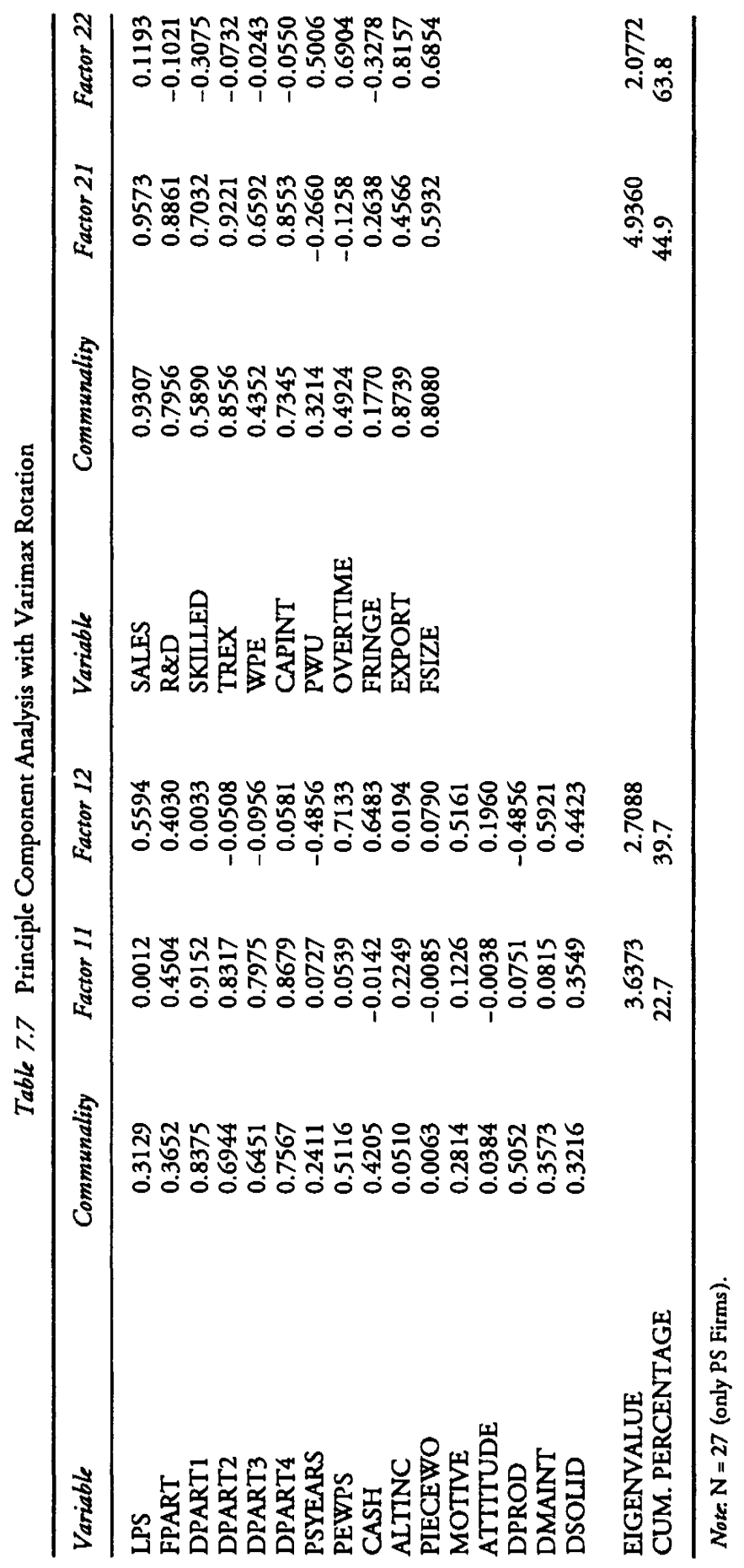




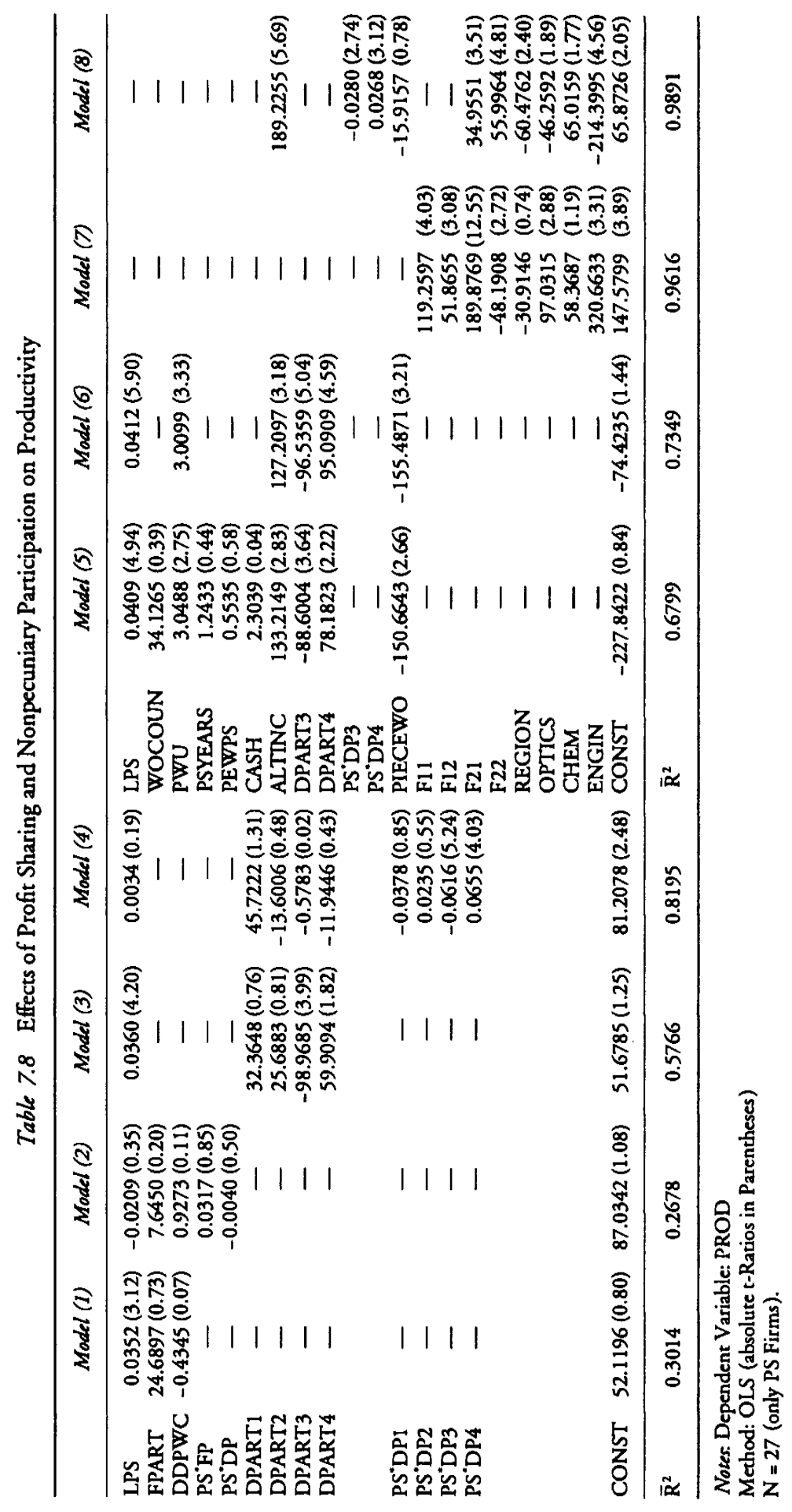




\section{PROFIT SHARING IN GERMAN FIRMS}

design increases and that in pay issues decreases productivity. Third, it is not unambiguous whether interaction effects predominate over direct PS and nonmonetary participation effects. Considering column 4 of Table 7.8, the results speak in favor of interaction effects. But factor analysis - see Table 7.7-obviously separates PS and participation effects. However, we do not know in which way factor 11 (F11) and factor 12 (F12) in Table 7.7 express different dimensions. It might be possible that independent from a specific reason F11 and F12 have to be separated but from the productivity view there is reciprocal reinforcement. The comparison of columns 7 and 8 in Table 7.8 supports this idea. In column 7 more information is incorporated than in column 8 , with the exception of the interaction between PS and nonpecuniary participation but the adjusted determination coefficient in 8 is higher than in 7. Therefore, we favor specification 8 with interaction effects. This means hypothesis $\mathrm{H} 8$ is preferred to A8.

\section{Comparison with U.S. Results}

Mitchell et al. (1990: 55) emphasize that statistical research by academics on profit sharing in the United States has been extremely limited. Weitzman and Kruse (1990) and Kruse (1993) summarize the results of econometric U.S. studies on productivity effects of profit sharing and present new evidence, respectively. Generally, the productivity effects of PS are consistently positive and in most investigations significant. However, biases might exist that lead to the preponderance of positive coefficients even if the true coefficient is zero. The publication process favors the dissemination of significantly positive results in the literature. The size of the effect varies almost certainly with the specification and the circumstances in which profit sharing is implemented. The mean estimated effect is calculated as 7.4 percent and the median estimate is 4.4 percent. The more recent study of Kruse (1992), who uses panel data from 1971 to 1985 obtains the following results:

1 The coefficient of the profit sharing dummy that represents the increase in productivity in the year in which PS was adopted is positive and statistically significant. The increase amounts to 3.4 percent.

2 The coefficient of the variable that measures the yearly change in productivity after adopting the profit sharing plan is positive, small, and insignificant.

3 Using the proportion of employees within the firm covered by PS instead of dummy variables, the estimated coefficient is three times larger; the other results, however, tend to remain unchanged.

4 Important differences between manufacturing and nonmanufacturing firms are not detected.

In comparison with our investigation it should be stressed that we do not dispose of panel data and the sample is much smaller. However, more information is incorporated. The explained variance of the productivity variable is definitely higher than in the U.S. study. From our empirical evidence we cannot conclude 
that PS really improves labor productivity independently of firms' characteristics, the level of PS and employees' degree of participation.

U.S. investigations jointly analyzing PS and nonpecuniary participation are scarce. Levine and Tyson (1990: 205), for example, mention a case study of Hewlett-Packard where Quality Circles, self-directed work teams, and a cash profit sharing plan exist. Although econometric results are not presented their conclusion - not only on the basis of the Hewlett-Packard case study -is that growing evidence exists concerning the positive interaction between PS and participation which is more than the sum of its parts. This is in accord with our findings. Employers evaluate the productivity effects and improved labormanagement relations in a slightly more positive way than employees. The only U.S. study in which the two factors, PS and participation, are analyzed by regressions is published by Mitchell et al. (1990). They demonstrate in contrast to our results the existence of direct PS and participation effects on productivity and no effects on interaction. Furthermore, if participation is split in substantive participation and information sharing, the latter variable does not have an impact on productivity. Our results support this evidence.

\section{CONCLUSIONS}

The major results of our investigation are the following:

1 There exists a wide range of voluntarily agreed PS schemes in Germany. Six main schemes have to be distinguished. The degree of diffusion differs between the schemes. This is partially determined by the legal framework. In our sample PS with a silent partnership predominates.

2 We found that the probability of the existence of a PS scheme is higher in firms with a large number of employees, a low degree of competition, low market shares, and favorable economic conditions than in other firms.

3 The positive productivity effects of PS are not so obvious as could be expected from the theoretical viewpoint. Alternative organizational structures and labor compensation systems often affect the economic performance of firms. Effects of nonpecuniary participation and of participatory arrangements which vary across institutional settings are more relevant in interaction with PS than as pure effects, a somewhat divergent result from that of a U.S. study.

The observed results which differ compared to other studies might be due to varying sample selection and to the measurement of PS, participation and economic performance.

Our results are preliminary in the sense that they are based on a small data set. We are in the process of extending the sample by incorporating profit sharing firms from North Rhine-Westfalia and of collecting information for a control group from the same federal state. Furthermore, we are involved in a second round of interviews in the PS firms. The control group of firms was already interviewed a second time. This procedure should be helpful to analyze time effects and to reduce 


\section{PROFIT SHARING IN GERMAN FIRMS}

the impact of unobserved variables. Furthermore, as Pendleton et al. (1991) emphasize, PS is an extremely complex phenomenon which can operate through a variety of processes, through the medium of attitudinal change. Therefore, it seems necessary to investigate further potential reactions of firms and workers to PS.

\section{ACKNOWLEDGMENTS}

We are grateful to the firms for providing the data and information without which this paper could not have been written, and to the German Science Foundation (DFG) for financial support. For helpful comments we thank Susan N. Houseman.

\section{NOTES}

1 To identify a potential bias in the data source which might stem from the fact that PS firms were interviewed by Infratest and the Institute for Quantitative Economic Research we performed the t-tests of the first part of Table 7.2 for these two subsamples of PS firms. With the exception of two additional variables (market policy concerning the most important product and the proportion of PS-eligible and actually participating employees) no significant differences were detected.

\section{REFERENCES}

Bera, A. K., Jarque, C. and Lee, L.-F. (1984) "Testing the Normality Assumption in Limited Dependent Variable Models," International Economic Review 25: 563-578.

Blasi, J. R. (1988) Employee Ownership: Revolution or Ripoff?, Cambridge, MA. (1990) "Comment" in A. S. Blinder (ed.), Paying for Productivity, Washington.

Blasi, J. R. and Kruse, D. L. (1991) The New Owners, New York.

Blinder, A. S. (1990) (ed.), Paying for Productivity, Washington.

Cable, J. (1988) "A Model and Measure of Employee Participation: Guttman Scale Tests of the Espinosa-Zimbalist Hypothesis," in D. C. Jones and J. Svejnar (eds), Advances in the Economics of Labour-Managed and Participatory Firms, 3, Greenwich.

Cable, J. and FitzRoy, F. (1980) "Productive Efficiency, Incentives and Employee Participation: Some Preliminary Results for West Germany," Kyklos 33: 100-121.

Cable, J. and Wilson, N. (1989) "Profit-sharing and Productivity: An Analysis of UK Engineering Firms," Economic Journal 99: 366-375.

Conte, M. A. and Svejnar, J. (1990) "The Performance Effects of Employee Ownership Plans," in A. S. Blinder (ed.), Paying for Productivity, Washington.

Davidson, R. and MacKinnon, J. G. (1984) "Convenient Tests for Logit and Probit Models," Journal of Econometrics 25: 241-262.

FitzRoy, F. (1990) "Profit Sharing Arguments-Macro- and Micro-economic Effects," University of St. Andrews, mimeo.

FitzRoy, F. and Kraft, K. (1985) "Mitarbeiterbeteiligung und Produktivität: Eine ökonometrische Untersuchung," Zeitschrift für Betriebswirtschaft 55: 21-36.

- (1986) "Profitability and Profit Sharing," Journal of Industrial Economics 35: $113-130$.

(1987) "Cooperation, Productivity and Profit Sharing," Quarterly Joumal of Economics 102: 23-37.

(1992) "Forms of Profit Sharing and Firm Performance: Theoretical Foundations and 
Empirical Problems," Kyklos 45: 209-225.

Gilman, N. P. (1891) Profit-sharing between Employer and Employee, New York.

Guski, H. G. and Schneider H. J. (1983) Betriebliche Vermögensbeteiligung in der Bundesrepublik Deutschland, Part II, Cologne.

(1986) "Betriebliche Vermögensbeteiligung, Bestandsaufnahme," Beiträge zur Wirtschafts- und Sozialpolitik 145, Institut der deutschen Wirtschaft, Cologne.

Hashimoto, M. (1979) "Bonus Payments, On-the-Job Training, and Lifetime Employment in Japan," Joumal of Political Economy 87: 1251-1271.

Heckman, J. J. (1979) “Sample Selection Bias as a Specification Error," Econometrica 47: 153-161.

Hübler, O. (1993) "Productivity, Earnings, and Profit Sharing-An Econometric Analysis of Alternative Models," Empirical Economics 18: 357-380.

Kruse, D. L. (1991) "Profit Sharing in the 1980s: Disguised Wages or a Fundamentially Different Form of Compensation?," in R. W. Eberts and E. L. Groshen (eds), Structural Changes in U.S. Labor Markets, Armonk, NY/London.

(1992) "Profit Sharing and Productivity. Microeconomic Evidence from the United States," Economic Journal 102: 24-36.

— (1993) "Profit Sharing-Does it make a Difference?," Kalamazoo, Mich.

Levine, D. and Tyson, L. (1990) "Participation, Productivity, and the Firm's Environment," in A. S. Blinder (ed.), Paying for Productivity, Washington.

McFadden, D. (1973) "Conditional Logit Analysis of Qualitative Choice Behavior," in P. Zarembka (ed.), Frontiers in Econometrics, New York.

Ministerium für Arbeit, Gesundheit, Familie und Sozialordnung des Landes BadenWürttemberg (1990) (ed.), Beteiligung am Produktivkapital, Stuttgart.

Mitchell, D. J., Lewin, D. and Lawler, E. E. (1990) "Alternative Pay Systems, Firm Performance, and Productivity," in A. S. Blinder (ed.), Paying for Productivity, Washington.

Orme, C. (1990) "The Small Sample Performance of the Information Matrix Test," Journal of Econometrics 46: 309-331.

Palokangas, T. (1992) "Binding Contracts, Profit-sharing and the Degree of Centralization," Joumal of Institutional and Theoretical Economics 148: 260-273.

Pendleton, A., Wilson, N. and Walley, K. (1991) "Profit Sharing and Employee Share Ownership: A Survey of Recent Developments in the UK," University of Bradford, mimeo.

Schanz, G. and Riekhof, H.-C. (1983) Mitarbeiterkapitalbeteiligung in der Wirtschaft Niedersachsens, Hannover.

Schneider, H.J. and Zander, E. (1990) Erfolgs- und Kapitalbeteiligung der Mitarbeiter in Klein- und Mittelbetrieben, Freiburg.

Steinherr, A. (1977) "On the Efficiency of Profit Sharing and Labor Participation in Management," Bell Journal of Economics 8: 545-555.

Thünen, J. H. von (1850) Der isolierte Staat in Beziehung auf Landwirtschaft und Nationalökonomie, zweiter Teil (second part) Der naturgemäße Arbeitslohn und dessen Verhälmis zu Zinsfuß und zur Landrente, Rostock.

Uvalic, M. (1991) "The Pepper Report. Promotion of Employee Participation in Profits and Enterprise Results in the Member States of the European Community," Florence/ Brussels: Commission of the European Communities.

Weitzman, M. L. (1983) "Some Macroeconomic Implications of Alternative Compensation Systems," Economic Journal 93: 763-783.

(1984) The Share Economy, Cambridge.

(1985) "The Simple Macroeconomics of Profit Sharing," American Economic Review 75: $937-953$.

- (1987) "Steady State Unemployment under Profit Sharing," Economic Joumal 97: 86-105. 
Weitzman, M. and Kruse, D. L. (1990) "Profit Sharing and Productivity," in A. S. Blinder (ed.), Paying for Productivity, Washington.

\section{APPENDIX: DEFINITION OF VARIABLES IN FIGURE AND TABLES}

\begin{tabular}{|c|c|}
\hline ABSENT & degree of absenteeism \\
\hline ALTINC & suggestions of alternative incentives to PS $(1=$ yes $)$ \\
\hline ATTITUDE & $\begin{array}{l}\text { has the employees' attitude to work positively changed after the adoption of } \\
\text { PS ( } 1=\text { yes) }\end{array}$ \\
\hline APC & $\begin{array}{l}\text { assessment of profits (per sales) compared to competitors }(1=\text { much better } \\
\ldots 5=\text { extremely worse) }\end{array}$ \\
\hline APPR & proportion of apprentices \\
\hline BJLT & test for normality (Bera et al. 1984) \\
\hline CAPE & proportion of capital held by employees \\
\hline CAPINT & capital intensity \\
\hline CASH & cash PS payment $(1=$ yes $)$ \\
\hline CHEM & $(1=$ chemical sector $)$ \\
\hline COMPET & degree of competition ( $1=$ low, $2=$ average, $3=$ high $)$ \\
\hline $\mathrm{CORR}^{2}$ & squared correlation between observed and expected values \\
\hline DABSENT & $\begin{array}{l}\text { dummy for reason to adopt PS }(1=\text { decline of absenteeism was an objective } \\
\text { of the introduction) }\end{array}$ \\
\hline DDPE & $\begin{array}{l}\text { degree of participation of the employees in decision making: dummy ( } 1 \text { if } \\
\text { DPARTE > 6) }\end{array}$ \\
\hline DDPWC & $\begin{array}{l}\text { degree of participation of the works council in decision making: dummy ( } 1 \\
\text { if DPARTWC }>6 \text { ) }\end{array}$ \\
\hline & $\begin{array}{l}\text { To determine DPARTWC (DPARTE) the degree of involvement in } \\
\text { decision making (beyond codified German codetermination) is considered } \\
\text { for the four fields: (a) investment and rationalization; (b) wage determina- } \\
\text { tion; (c) personnel; (d) workplace and then scored: no ( } 0 \text { points), access to } \\
\text { information ( } 1 \text { point), discussion ( } 2 \text { points), worker initiated changes ( } 3 \\
\text { points). The sum of scores constitutes DPARTWC (DPARTE). }\end{array}$ \\
\hline DEFFWAGE & dummy ( 1 if actual wage level exceeds bargained wage level) \\
\hline DF & degree of freedom \\
\hline DFAIR & dummy for reason to adopt PS $(1=$ fairness...) \\
\hline DFLUCT & dummy for reason to adopt PS ( 1 = reduction of fluctuation...) \\
\hline D84 & $\begin{array}{l}\text { dummy for introduction of PS relative to the Property Development Act in } \\
1984(1=\text { introduction after } 1984)\end{array}$ \\
\hline DLEGAL & dummy for reason to adopt PS ( $1=$ legal subsidies ...) \\
\hline DMAINT & dummy for reason to adopt PS ( 1 = improved maintenance of material...) \\
\hline DMT & $\begin{array}{l}\text { test for homoscedasticity of all exogenous variables (Davidson and } \\
\text { MacKinnon 1984) }\end{array}$ \\
\hline DPART1 & participation of works council in investment and rationalization $(0,1,2,3)$ \\
\hline DPART 11 & participation of employees in investment and rationalization $(0,1,2,3)$ \\
\hline DPART2 & participation of works council in personnel decisions $(0,1,2,3)$ \\
\hline DPART21 & participation of employees in personnel decisions $(0,1,2,3)$ \\
\hline DPART3 & participation of works council in pay issues $(0,1,2,3)$ \\
\hline DPART31 & participation of employees in pay issues $(0,1,2,3)$ \\
\hline DPART4 & participation of works council in job design $(0,1,2,3)$ \\
\hline DPART41 & participation of employees in job design $(0,1,2,3)$ \\
\hline
\end{tabular}


VIVIAN CARSTENSEN, KNUT GERLACH, OLAF HUBLER

\begin{tabular}{|c|c|}
\hline DPARTE & $=$ DPART11 + DPART21 + DPART31 + DPART41 \\
\hline DPARTWC & =DPART1 + DPART2 + DPART3 + DPART4 \\
\hline DPPS & dummy $(1=$ private pension system exists $)$ \\
\hline DPROD & dummy for reason to adopt PS ( $1=$ to increase productivity...) \\
\hline DPS & dummy ( 1 = profit sharing exists $)$ \\
\hline DQUAL & $\begin{array}{l}\text { dummy for reason to adopt PS }(1=\text { attraction of highly qualified } \\
\text { workers...) }\end{array}$ \\
\hline DSEN & dummy $(1=$ seniority wages are paid $)$ \\
\hline DSOLID & $\begin{array}{l}\text { dummy for reason to adopt } \text { PS }^{2}(1=\text { to improve partnership and solidarity } \\
\text { between management and workers...) }\end{array}$ \\
\hline DTREX & $\begin{array}{l}\text { dummy }(1=\text { financial support of the firm for further training of the } \\
\text { employees) }\end{array}$ \\
\hline EFFWAGE & ratio of actual to bargained wage \\
\hline EFLUCT & dummy for effect of PS ( 1 = PS reduced fluctuation) \\
\hline ELIG & proportion of eligible employees (for PS firms only) \\
\hline ENGIN & dummy ( 1 = engineering sector) \\
\hline EPROD & dummy for effect of PS ( $1=$ PS increased productivity) \\
\hline ESOLID & dummy for effect of PS ( 1 = PS improved solidarity) \\
\hline EXPORT & exports per sales \\
\hline FEXP & $\begin{array}{l}\text { assessment of former experience }(1=\text { extremely negative } \ldots 5=\text { extremely } \\
\text { positive) }\end{array}$ \\
\hline FPART & formal (representative) participation in decision making: \\
\hline & $\begin{array}{l}\text { FPART }=\mathrm{QCC}+\mathrm{TW}+\mathrm{JLMC} \text { (aggregate of formal institutions: quality } \\
\text { circle }(\mathrm{QCC} \text { ), team work (TW), regular joint labor-management consulta- } \\
\text { tion committees (JLMC) measured as dummies) }\end{array}$ \\
\hline FRINGE & firm specific fringe benefits (nonwage labor costs) \\
\hline FSIZE & firm size (number of employees) \\
\hline FSIZEC & $\begin{array}{l}\text { classes of firm size ( } 1=5-49 \text { employees, } 2=50-199 \text { employees, } 3=>200 \\
\text { employees) }\end{array}$ \\
\hline F11 & $\begin{array}{l}\text { factor scores of factor } 1 \text { from principal component analysis to PS- } \\
\text { participation variables }\end{array}$ \\
\hline F12 & factor scores of factor 2 from ... to PS-participation variables \\
\hline F21 & cores of factor 1 from ... to firms' characteristics \\
\hline $\mathrm{F} 22$ & 2 from ... to firms' characteristics \\
\hline HIER & number of hierarchical levels \\
\hline IMT & information matrix test for correct specification (Orme 1990) \\
\hline INNOV & dummy ( $1=$ firm introduced new or substantially improved products) \\
\hline INVEST & investment per sales \\
\hline INVOL & proportion of PS participating employees (for PS firms only) \\
\hline IPART & $\begin{array}{l}\text { participation as incentive to increase effort }(1=\text { very suitable } \\
\ldots .5=\text { unsuitable })\end{array}$ \\
\hline IPROM & promotion as incentive... \\
\hline & profit sharing as incentive... \\
\hline LLF & log-likelihood funcrion \\
\hline LPS & level of profit sharing \\
\hline LRT & likelihood ratio test statistic \\
\hline MCUST & number of major customers $(0=$ none, $1=1,2=2-10)$ \\
\hline MARKUP & $\begin{array}{l}\text { ranking score across the external proxy for the gross profit situation of a } \\
\text { sector: (value added-labor costs) per sales. Eleven sectors are considered } \\
\text { ( } 1=\text { sector with worst situation ... 11 = sector with/ best situation). }\end{array}$ \\
\hline & dummy $(1=$ metal products sector $)$ \\
\hline & Is PS a motivation for workers to apply to a firm for a position? ( $1=$ yes) \\
\hline
\end{tabular}




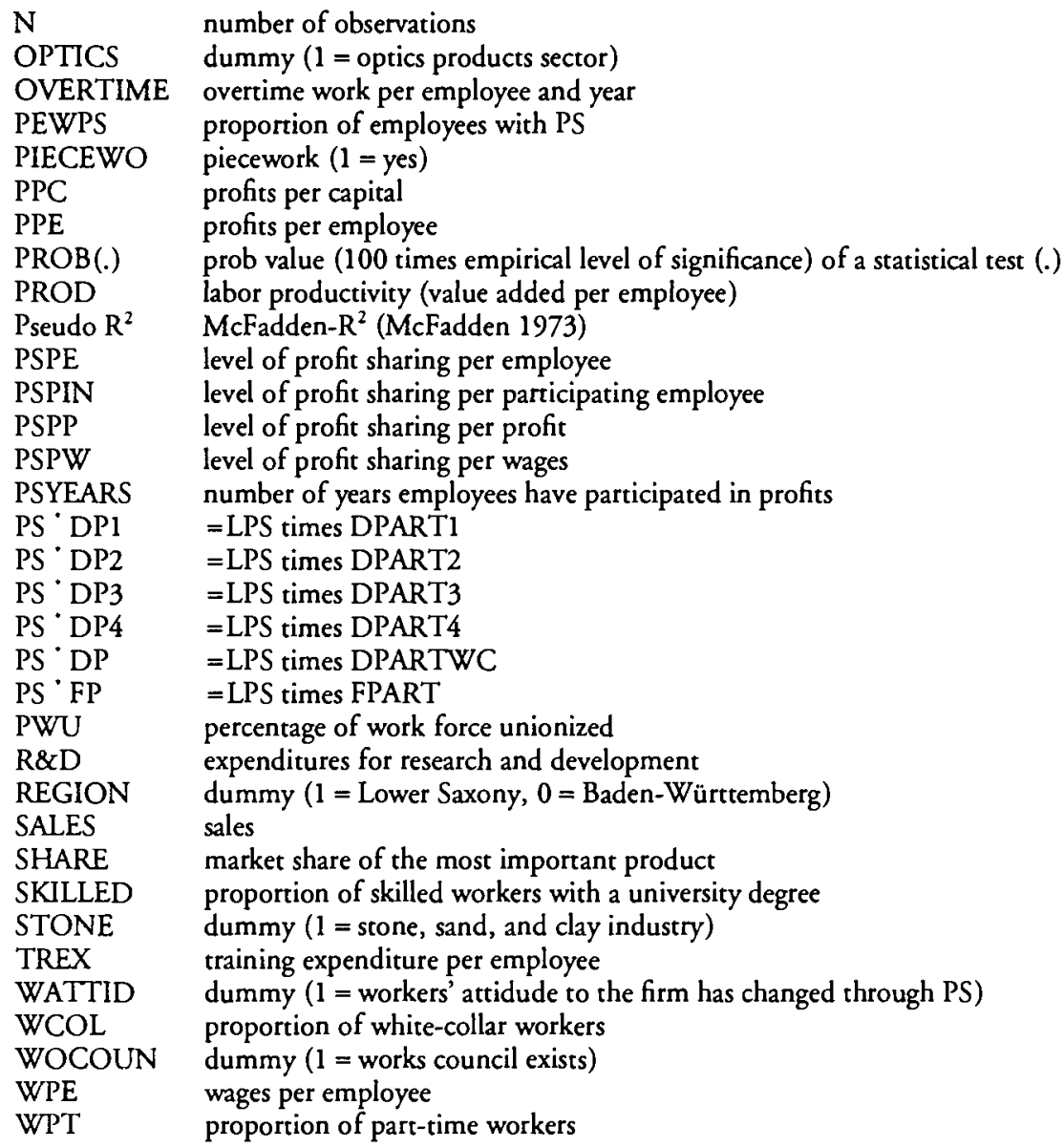

